\title{
Review
}

\section{Newly Developed Self-Assembling Antioxidants as Potential Therapeutics for the Cancers}

\author{
Babita Shashni ${ }^{1}$ and Yukio Nagasaki ${ }^{1,2,3, *(D)}$ \\ 1 Department of Materials Science, Graduate School of Pure and Applied Sciences, University of Tsukuba, \\ Tennoudai 1-1-1, Tsukuba, Ibaraki 305-8573, Japan; shashni@ims.tsukuba.ac.jp \\ 2 Master's School of Medical Sciences, Graduate School of Comprehensive Human Sciences, \\ University of Tsukuba, Tennoudai 1-1-1, Tsukuba, Ibaraki 305-8573, Japan \\ 3 Center for Research in Isotopes and Environmental Dynamics (CRiED), University of Tsukuba, \\ Tennoudai 1-1-1, Tsukuba, Ibaraki 305-8573, Japan \\ * Correspondence: happyhusband@nagalabo.jp; Fax: +81-(0)29-853-5750
}

\section{check for}

updates

Citation: Shashni, B.; Nagasaki, Y. Newly Developed Self-Assembling Antioxidants as Potential

Therapeutics for the Cancers. J. Pers. Med. 2021, 11, 92. https://doi.org/ $10.3390 /$ jpm 11020092

Academic Editor: Hiroshi Maeda

Received: 14 December 2020

Accepted: 28 January 2021

Published: 2 February 2021

Publisher's Note: MDPI stays neutral with regard to jurisdictional claims in published maps and institutional affiliations.

Copyright: (c) 2021 by the authors. Licensee MDPI, Basel, Switzerland. This article is an open access article distributed under the terms and conditions of the Creative Commons Attribution (CC BY) license (https:/ / creativecommons.org/licenses/by/ $4.0 /)$.

\begin{abstract}
Elevated reactive oxygen species (ROS) have been implicated as significant for cancer survival by functioning as oncogene activators and secondary messengers. Hence, the attenuation of ROS-signaling pathways in cancer by antioxidants seems a suitable therapeutic regime for targeting cancers. Low molecular weight (LMW) antioxidants such as 2,2,6,6-tetramethylpyperidine-1-oxyl (TEMPO), although they are catalytically effective in vitro, exerts off-target effects in vivo due to their size, thus, limiting their clinical use. Here, we discuss the superior impacts of our TEMPO radicalconjugated self-assembling antioxidant nanoparticle (RNP) compared to the LMW counterpart in terms of pharmacokinetics, therapeutic effect, and adverse effects in various cancer models.
\end{abstract}

Keywords: cancer; reactive oxygen species; antioxidant; self-assembling drug

\section{Introduction}

Reactive oxygen species (ROS) are intracellular free oxygen radicals with one or more unpaired electrons in their valency shell. These unpaired electrons are capable of independent existence and are highly reactive, who tend to stabilize their shell by donating or extracting electron(s) from the oxidizable molecules. These target oxidizable molecules become a radical entity, which further starts a chain reaction of damaging other molecules [1]. The concept of organic free radical began in 1900 by Gomberg, who speculated the presence of triphenyl methyl radical $\left(\mathrm{Ph} 3 \mathrm{C}^{\bullet}\right)$ in the living system. In 1954, a free radical theory was proposed by Gershman, who pointed out the toxicity of oxygen and its reduced forms due to the highly oxidizing power [2,3]. In 1969, McCord and Fridovich discovered the first cellular antioxidant enzyme, superoxide dismutase (SOD) [4].

ROS are broadly classified into radical and non-radical species. Radical species involve entities with unpaired electron(s) such as superoxide $\left(\mathrm{O}_{2}{ }^{\bullet-}\right)$, hydroxyl radical $\left(\mathrm{OH}^{\bullet-}\right)$, oxygen biradicals $\left(\mathrm{O}_{2} \bullet \bullet\right)$, peroxyl radicals $\left(\mathrm{ROO}^{\bullet}\right)$, and alkoxy-radicals $\left(\mathrm{RO}^{\bullet}\right)$. In contrast, non-radical species include entities that do not contain an unpaired electron but can easily convert to free radicals in the living system. The primary reported species are hydrogen peroxide $\left(\mathrm{H}_{2} \mathrm{O}_{2}\right)$, hypochlorous acid $(\mathrm{HOCl})$, ozone $\left(\mathrm{O}_{3}\right)$, singlet oxygen $\left({ }^{1} \mathrm{O}_{2}\right)$, organic peroxides ( $\mathrm{ROOH})$, aldehydes ( $\mathrm{RCHO})$, and so on [5]. ROS can be produced both through endogenous and exogenous sources. Endogenous sources of ROS are mitochondria, peroxisomes, endoplasmic reticulum, and activated inflammatory neutrophils. Large amount of ROS is generated in mitochondria via several enzymatic reactions such as an electron transport chain, $\mathrm{NADH}$ dehydrogenase, and ubiquinone cytochrome $\mathrm{C}$ reductase, etc. Several enzymatic reactions generate ROS in peroxisomes ( $\beta$-oxidation of fatty acids; acyl CoA oxidase, uric acid metabolism; urate oxidase, xanthine metabolism; xanthine oxidase, D-proline metabolism; D-amino acid oxidase), and in the endoplasmic reticulum 
(cytochrome P450, b5 enzymes, diamine oxidase, thiol oxidase enzyme Erop1p). Activated inflammatory cells such as neutrophils also produce numerous ROS in the inflammatory sites.

In contrast, exogenous sources include pesticides, ultraviolet light, air, and water pollution, metals such as iron, copper, cobalt, cadmium, arsenic, etc. [6,7]. Under normal conditions, a small amount of ROS escapes during the intracellular processes regulated by the enzymatic antioxidant system, viz., superoxide dismutase, catalase, peroxiredoxins, glutathione peroxidases, glutathiones, bilirubin, etc. [6]. Although antioxidant systems maintain a tightly controlled redox homeostasis in the normal cells, irreversible or nonrepairable oxidative damage to nuclear and mitochondrial DNA, protein, and lipids are inevitable due to their prolonged overexposure to exogenous ROS producers. These overproduced ROS lead to oxidative stress-related diseases such as cancer, cardiovascular diseases, diabetes, rheumatoid arthritis, neurogenerative diseases, liver disease, and ischemic and post-ischemic pathologies [6-8]. Exogenous oxidative stress or prolonged chronic endogenous oxidative stress such as inflammation has been linked to tumor initiation, promotion and progression, which are evident from the fact that cancer cells are under constant oxidative stress, a hallmark of cancerous phenotype [8,9]. Considering a continuous elevated ROS level in the tumor environment, which is crucial for tumorigenesis, metastasis, and angiogenesis, antioxidant therapies seem to be the most intuitive and apt intervention to attenuate various cancers. Although various low molecular weight (LMW) antioxidants such as vitamin C, vitamin E, selenium, and TEMPOL, showed effectiveness in vitro and in some cases in vivo; however, clinically, they failed to show any conclusive efficacy [10]. Their clinical failure may be attributed to their metabolism and rapid excretion, preventing them from reaching the target ROS production site of the tumor cells in enough amount to scavenge ROS to a critical level to have sufficient anti-cancer efficacy. Another significant and severe problem of the LMW antioxidants is that they internalize in the healthy cells and disturb their redox homeostasis, including the mitochondrial electron transport chain. Here, we conceptualized new antioxidants, "self-assembling antioxidants", which significantly vary in their pharmacokinetic characteristics and reduce undesired adverse side effects related to the LMW antioxidants. In this review, an implication of ROS in cancer, the status of antioxidant cancer therapies using LMW compounds and the precedence of self-assembling antioxidants (we abbreviate them as redox nanoparticle hereafter; RNP) over LMW antioxidant compounds for the cancer therapeutics will be discussed in detail.

\section{Oxidative Stress and Cancer}

As described in the above section, evidence from the clinical and bench studies indicate that the elevated intracellular ROS contributes to cancer initiation, promotion and progression $[8,9]$. The intracellular antioxidant system can quench the overproduced ROS generated through the exogenous source or chronic inflammation in the normal cells to some extent and under their capacity. However, ROS that could not be completely eliminated could be mutagenic and induce carcinogenesis [9,11,12]. For instance, white blood cells convert to neutrophils and invade the inflamed colon in ulcerative colitis. These activated neutrophils generate $\mathrm{ROS}$ such as $\mathrm{O}_{2}{ }^{\bullet-}$ and $\mathrm{HOCl}$, which are known to stimulate mutagenesis and cause colon cancer [13,14]. Similarly, constant exposure to free radical producers such as ultraviolet, tobacco smoke, and metal ions may stimulate mutagenesis and induce melanoma, bronchogenic carcinoma, and colorectal cancer, respectively [8].

Tumor initiation is triggered by damaging cellular genes, mainly by the oxidation with ROS. It is reported that about 10,000 oxidative hits to DNA per cell are observed daily in humans [15], which are eventually recovered by the cellular repairing system. However, sometimes, when oxidative stress damage is beyond their repair capacity, DNA base adduct with non-scavenged ROS may be observed [8,16]. For instance, one of ROS, hydroxide radical $(\bullet \mathrm{OH})$ attacks the guanine $(\mathrm{G})$ base at the eighth position to become 8-OH-G, which leads to Guanine-Cytosine to Thymine-Adenine transversion, called point 
mutation $[8,16,17]$. In addition, DNA helix alterations such as single or double-strand breaks and inter-strand crosslinks are also observed upon damage by free radicals generated through ultraviolet or ionizing lights $[18,19]$. Such alteration in the DNA results in genomic instability, which may further modulate transcription and transduction pathways favoring carcinogenesis and tumor progression [20,21].

ROS in tumors participates in the intracellular signaling and regulation by acting as secondary messengers [6-8]. Ras protein family, one of the membrane-bound G protein families, regulates transcription, cell growth, and apoptosis [22]. Ras is activated by ROS derived from ultraviolet radiation and metal ions and is known to be frequently mutated in humans cancers such as skin, liver, and colon cancers [22]. It should be noted that Ras-dependent cell proliferation requires ROS, which is unconditionally elevated in cancers [23].

Another tumor suppressor protein, p53, a transcriptional factor, is known to be involved in cell cycle arrest, senescence, apoptosis, DNA repair, and redox homeostasis [24-26]. Upon oxidative stress by ionizing radiation or genotoxic insults, DNA lesions are accumulated, which are repaired before the DNA replication by arresting the cell cycle. Once the DNA lesion is repaired, the normal cell resumes cell division. p53, known as "the guardian of the genome", preserves this DNA integrity [27]. However, when the TP53 gene is mutated, the DNA damage is carried down to several cell divisions, leading to chromosomal rearrangement [28]. TP53 gene is often known to be mutated in various solid cancers [27].

Another popular redox-sensitive transcription factor is NF-kB, which is reported to be involved in cell survival, differentiation, growth, angiogenesis, and inflammation [29,30]. $\mathrm{NF}-\mathrm{kB}$ is activated by carcinogenic stimuli such as ultraviolet radiation, phorbol esters, toxic metals, and asbestos, all of which are oxidative stress inducers [31]. Although it is evident from several reports that ROS activates NF-kB, recent studies confirm the bidirectional regulation by ROS, which is not clearly understood [30]. Nonetheless, it is reported that the NF-kB pathway is often excessively activated in tumor tissues, promoting tumor cell proliferation and survival [32].

It is reported that ROS also activates protein kinases $\mathrm{C}$ (PKCs), critical for cancer proliferation, by increasing the cytosolic calcium concentration and the cysteine oxidization of their regulatory domains $[33,34]$. This activates downstream cell proliferation, differentiation, and apoptosis pathways, involving mitogen-activated protein kinases (MAPKs) such as extracellular-regulated (ERKs), c-jun- $\mathrm{NH}_{2}$-terminal kinase (JNKs), and p38 MAPK [35]. Furthermore, ROS also regulates hypoxia-inducible factor, HIF-1, in tumors, which further modulates many cancer-related genes, such as VEGF, involved in tumor progression and angiogenesis [36]. Other ROS-sensitive regulatory proteins such as AP-1 and nuclear factor of activated T cells are also known to be involved in tumorigenesis [37-39]. Interestingly, ROS also regulates pro-proliferative signaling in tumors and prevent apoptosis by activation of proto-oncogene BCL-2, which is an anti-apoptotic protein. BCL-2 family is overexpressed in many cancers such as breast, lung, colorectal, and melanoma, which not only prevents tumor cell death but also promotes their migration, invasion, and metastasis [40].

From the evidence stated above, it is obvious that oxidative stress is critical for tumor initiation and growth by inducing genomic instability and acting as signaling molecules to modulate factors favoring tumorigenesis, angiogenesis, and metastasis, respectively. Since the critical roles of the elevated ROS-signaling pathways are revealed in various cancers, the antioxidant therapies seem to be the most appropriate strategy to impede their growth. The next section will discuss the status of conventional antioxidants for cancer therapy.

\section{Conventional Antioxidants for Potential Cancer Therapy}

As mentioned above, since ROS is strongly associated with carcinogenesis, tumorigenesis, and metastasis, antioxidant treatments to inhibit cancers have been investigated. Sharma et al. reported that patients with locally advanced squamous cell carcinoma of the tongue had significantly elevated plasma lipid peroxidation levels and conjugated 
dienes. At the same time, primary endogenous antioxidants such as glutathione, vitamin $C$, vitamin E, glutathione peroxidase, and superoxide dismutase were significantly decreased, as compared to the healthy controls, implying that oxidative stress plays an essential role in the pathophysiology of tongue cancer [41]. Considering the critical role of ROS in tumors, various antioxidants, including natural antioxidants have been tested to dampen the ROS levels as therapeutic interventions. Numerous natural and synthetic antioxidants have been investigated as potential anti-cancer drugs. These investigations have shown positive effects in vitro and/or in vivo against various cancer models. For example, one of the famous synthetic antioxidants, N-acetylcysteine (NAC), has shown the anti-cancer effect on prostate carcinoma, PC-3 cells (in vitro) and human tongue squamous carcinoma, HSC-3 cells (in vivo) [42,43]. Natural vitamins are also reported to exert anti-cancer effects. For instance, vitamin C inhibited invasion and metastasis of breast cancer cells (in vivo) and impaired tumor growth and eradicated liver cancer stem cells in the xenograft model of a hepatocellular carcinoma cell line $[44,45]$. Vitamin E analog, RRR- $\alpha$-tocopherol succinate, is known to induce apoptosis mediated death in MDA-MB435, MDA-MB231, and SKBR-3 human breast cancer cells [46,47]. Quercetin, a bioflavonoid, is also known to inhibit cancer growth by arresting the cell cycle and induced apoptosis in breast cancer, prostate cancer and colorectal cancer [48-50].

TEMPOL, a redox-cycling nitroxide (4-hydroxy-TEMPO; 4-hydroxy-2,2,6,6-tetramethylpiperidine-1-oxyl), is known as a probe of electron spin resonance due to the presence of unpaired electron in the compound. Since this unpaired spin is stable because of the steric hindrance of the surrounding four methyl groups, so they do not react to each other. However, it is known that TEMPOL can rapidly react with free radicals of ROS. Thus, they can be regarded as one of the most potent antioxidants, like a superoxide dismutase [51]. Luo et al. reported a comparative superoxide inhibition activity of TEMPOL and several other antioxidants in angiotensin II-stimulated preglomerular vascular smooth muscle cells assessed by lucigenin-enhanced chemiluminescence. They confirmed that PEGylated-SOD and TEMPOL exhibited the maximum catalytic actions to scavenge $\mathrm{O}_{2}{ }^{\bullet-}$ than NAC, vitamin $\mathrm{C}$ and $\mathrm{E}$ analogues such as ascorbate, $\alpha$-tocopherol and 6-hydroxy-2,5,7,8-tetramethylkroman-2-carboxy acid (Trolox) and other uncharacterized antioxidants; 5,10,15,20-tetrakis (4-sulphonatophenyl)porphyrinate iron (III)(FeTTPS), 2-phenyl-1,2-benzisoselenazol-3(2H)-one (ebselen), nitroblue tetrazolium (NBT) and (-)-cis-3,3' $4^{\prime}, 5,7-$ pentahydroxyflavane (2R,3R)-2-(3,4-dihydroxyphenyl)-3,4-dihydro-1(2H)benzopyran-3,5,7-triol(-epicatechin) [51,52]. With such high catalytic activity, TEMPOL has been the most preferred choice for antioxidant-based therapy for various oxidative stressrelated models such as fibrosis, diabetes, neurodegenerative diseases, radio-protection, ischemia-reperfusion injury and inflammation, hypertension, and cancer [53]. Several studies have demonstrated that TEMPOL inhibits tumor growth and decreases tumor incidence. For instance, TEMPOL induced apoptotic cell death in MDA-MB231 breast cancer cell line [54]. Gariboldi et al. reported the inhibitory effects of TEMPOL on the growth of neoplastic than non-neoplastic cell lines such as breast cancer cell line MCF-7, p53-negative human leukemia cell line HL60, and C6 glioma cells [55-57]. Schubert et al. reported that dietary TEMPOL administration to ataxia telangiectasia mutated (ATM)-deficient young mice (develop tumors), prolonged latency to tumors, decreased ROS and oxidative damage, and increased their life span [58]. Corroborating this, Mitchell et al. confirmed that long-term TEMPOL treatment decreased spontaneous tumorigenesis in C3H mice [59]. TEMPO (2,2,6,6-tetramethylpiperidine-1-oxyl) administration into LNCaP tumor-bearing mice also showed significant inhibition to prostate tumor growth [60].

As described above, there are many publications about antioxidant-based cancer chemotherapy. Although numerous antioxidants have been proposed as an efficient anticancer agent in vitro and in vivo, these antioxidants failed to show any cumulative effect clinically on healthy, at-risk, and cancer population [10]. For instance, daily supplementation with selenium $(200 \mu \mathrm{g})$ and/or Vitamin E (400 IU) did not reduce the incidence of prostate or other cancers. Instead, vitamin E supplementation resulted in $17 \%$ increase in 
prostate cancer incidence $[61,62]$. Corroborating this, daily supplementation of $\beta$-carotene (50 mg) also did not reduce the incidence of prostate cancer or other cancers [63]. However, daily supplementation of beta-carotene $(15 \mathrm{mg})$, alpha-tocopherol (30 $\mathrm{mg})$, and selenium $(50 \mu \mathrm{g})$ to Chinese at-risk population of developing esophageal cancer and gastric cancer reduced cancer mortality associated with gastric cancer, no effect was seen in esophageal cancer suffering population [64]. In another clinical study, a population who were occupationally exposed to asbestos were supplemented with $\beta$-carotene $(30 \mathrm{mg}$ ) and retinyl palmitate $(25,000 \mathrm{IU})$ daily, which tended to associate with increased lung cancer incidence and mortality [65].

Such contrasting effects of conventional antioxidants in tumorigenesis and inconclusive clinical trials indicate that these conventional antioxidants cannot be used for anti-cancer therapy. Because several elegant studies confirmed the role of elevated ROS in cancer, it is striking to see the failure of antioxidant-based cancer therapy. Their clinical failure could be attributed to several factors such as the level and the location of ROS scavenged and the tumor stage at which antioxidants were introduced. In addition, since most conventional antioxidants are LMW, their extremely rapid renal clearance and very low bioavailability may have led to their insufficient accumulation in the tumors resulting in low efficacy.

Another significant problem with the conventional antioxidants is their molecular size-based adverse effects. Mitochondria in the healthy cells generate ATP via an electron transport chain by oxidation of glucose. During this process, a considerable amount of ROS is produced. LMW antioxidants can rapidly spread to the entire body and internalize into the healthy cells, which causes the dysfunction of the essential redox homeostasis, including the electron transport chain, known as "Mithohormesis" [66]. It is reported that treatment with beta carotene, vitamin $\mathrm{A}$, and vitamin $\mathrm{E}$ increased mortality in a randomized clinical investigation of more than 230,000 participants [67]. This means that high dose of LMW antioxidants cannot be administered due to their ability to damage mitochondria. Contrarily, the limited dose of the LMW antioxidants may scavenge low ROS sufficiently to stimulate the survival and proliferation of tumor cells rather than impeding it. This was evident in the studies by Gal et al., who reported that administration of NAC and Trolox, Vitamin E analog, increased lymph node metastasis of malignant melanoma [68]. Furthermore, due to the limited dose and poor pharmacokinetic properties, it is also possible that in clinical trials, LMW antioxidants did not reach the target location to quench crucial ROS, e.g., mitochondria of cancer cells. Porporato et al. reported that mitochondrial superoxide promotes migration, invasion, and clonogenicity of tumor cells, which was prevented upon its scavenging [69].

As mentioned above, most antioxidants are small molecules, which contributes to poor bioavailability, prevents target accumulation and causes mitochondrial damage. To overcome these limitations of LMW antioxidants, a delivery platform (nanoparticle) to modulate their pharmacokinetics property has been employed. Nanoparticles-based delivery of antioxidants may scavenge ROS below critical levels in tumors to inhibit their growth due to their higher bioavailability and enhanced permeability and retention (EPR) effects as compared to their LMW counterparts [70]. Several groups have reported the use of antioxidants with various delivery (drug delivery system; DDS) platforms. For example, quercetin-encapsulated liposomes showed in vitro anti-proliferation effect on the breast cancer cells, MCF-7 [71]. Nanoparticles with intrinsic redox ability also showed anti-proliferative and anti-tumor effects, such as mesoporous silica nanoparticles and cerium oxide nanoparticles [72,73]. However, several antioxidant-based delivery platforms have shown practical inhibitory effects in vitro with limited or no in vivo application. Furthermore, silica and cerium oxide have been reported to exert toxicity in mice models with biodegradability issues, thereby limiting their further use [72,74]. One of the major problems with conventional DDS is that the physically encapsulated drug leaks out of the system before reaching their target, which diminishes their efficacy and increases adverse effects. In order to achieve effective antioxidant cancer chemotherapy, a new 
strategy should be required to overcome the limitation of nanoparticles with physically encapsulated antioxidants. For the last decade, we have devoted a novel designed selfassembling antioxidants to treat oxidative stress-related diseases. The next section will discuss the design, structure, and advantages of our newly developed self-assembling antioxidants for cancer therapy.

\section{Novel Self-Assembling Antioxidants; Nitroxide Radical-Containing Nanoparticle (RNP)}

\subsection{Design and Structure of RNPS}

Although TEMPO is one the most potent antioxidants known, similar to the antioxidant enzyme, SOD, its clinical use is greatly limited due to its off-target effects, which can be attributed to its poor pharmacokinetic properties as stated above. In order to improve the pharmacokinetic properties to obtain high efficacy with negligible off-target effects, we have functionalized TEMPO and developed two different types of nitroxide radicalcontaining nanoparticles (RNPs); $\mathrm{pH}$-sensitive $\left(\mathrm{RNP}^{\mathrm{N}}\right)$ and $\mathrm{pH}$-insensitive $\left(\mathrm{RNP}^{\mathrm{O}}\right)$, and evaluated their ROS-reduction mediated anti-cancer effect in various in vitro and in vivo models of cancers as stand-alone or as adjuvants to reduce the aggressiveness or sensitize several cancers for the chemotherapy (Figure 1). Since TEMPO possesses an unpaired electron, it is an electron spin resonance (ESR) active species, which could be used for magnetic resonance imaging and pharmacokinetic studies. This property along with its powerful ROS scavenging ability, prompted us to employ TEMPO over other LMW antioxidants for developing self-assembling antioxidants for the biomedical applications [53,75,76].

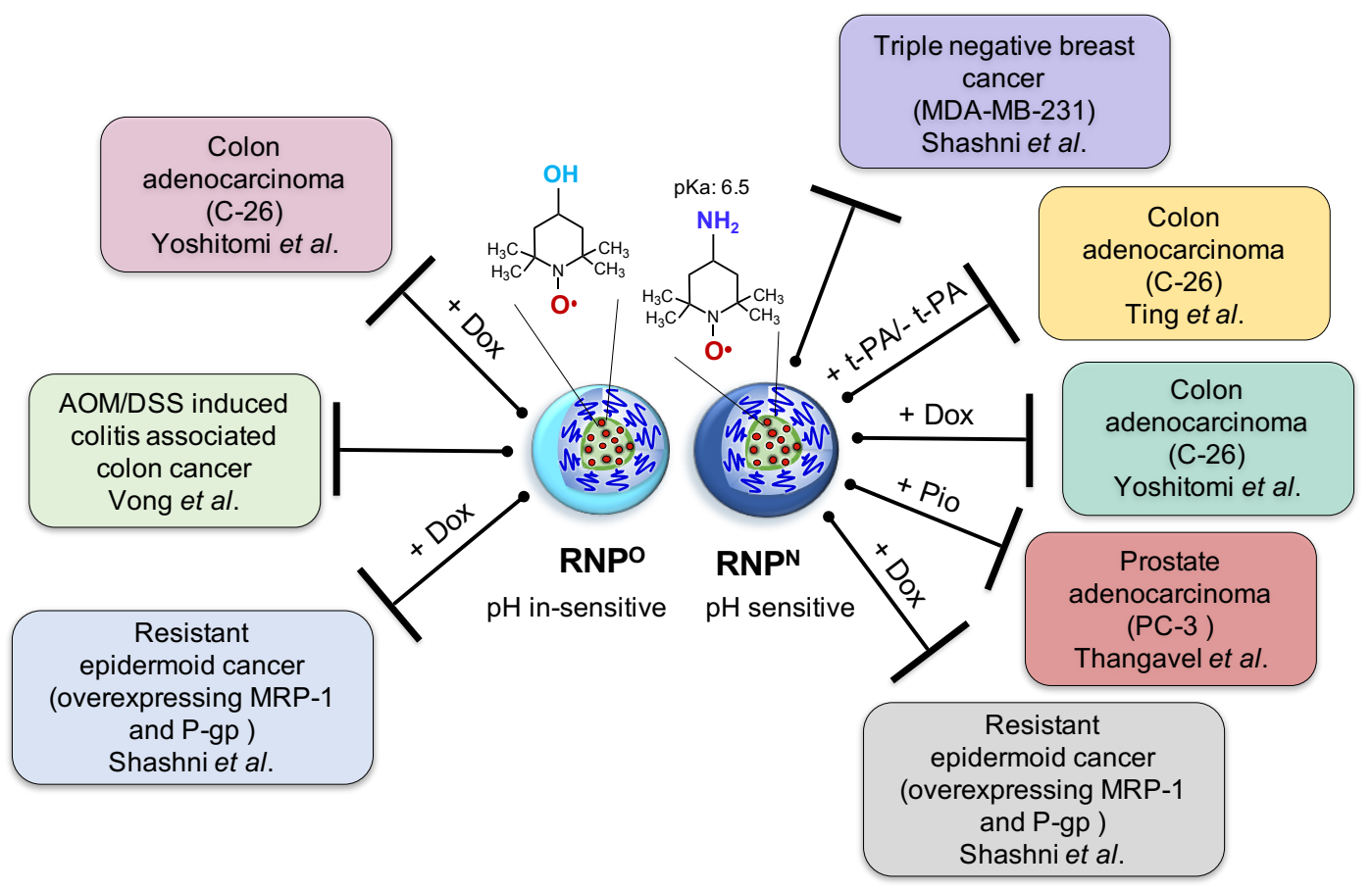

Figure 1. Illustration displaying the therapeutic efficacy of $\mathrm{pH}$ sensitive redox nanoparticle $(\mathrm{RNP})^{\mathrm{N}}$ and $\mathrm{pH}$ in-sensitive $\mathrm{RNP}^{\mathrm{O}}$ in various cancer models as stand-alone or as adjuvants with conventional anti-cancer drugs; doxorubicin (Dox) and pioglitazone (Pio).

RNPs are comprised of self-assembling amphiphilic block copolymer consisting of a hydrophilic poly (ethylene glycol) (PEG) segment and a hydrophobic poly (chloromethylstyrene) (PCMS) segment (Figure 2a). The chloromethyl groups of the PCMS segment are converted to TEMPO via the substitution of PEG-b-PCMS polymer with either 4amino-TEMPO or with 4-hydroxyl-TEMPO to form base polymers: PEG- $b$-PMNT and PEG- $b$-PMOT, respectively [75-78]. Under physiological conditions, the block copolymer 
assembles into a core shell-type micelles with the hydrophobic segment (PMNT or PMOT, which contains TEMPO moieties as a side chain) in the core and hydrophilic PEG in the shell (cumulative average diameter of approximately $20-50 \mathrm{~nm}$ ).

Since TEMPO moiety conjugates via ether linkage to the PMOT segment, PEG- $b$ PMOT gives a $\mathrm{pH}$-insensitive $\mathrm{RNP}^{\mathrm{O}}$. In contrast, $\mathrm{PEG}-b$-PMNT gives $\mathrm{pH}$-sensitive $\mathrm{RNP}^{\mathrm{N}}$, because TEMPO conjugates to the PMNT segment via the amine linkage, which protonates under the acidic environment and changes its water solubility. Since the pKa of the amino group of the PMNT segment is ca. 6.5, most of the amino groups in $\mathrm{RNP}^{\mathrm{N}}$ are not protonated under physiological conditions. However, under the acidic conditions, the protonated amine in the PMNT segment increases, converts their hydrophobic character to the hydrophilic, which weakens the core-coagulation force, leading to the collapse the micelle. Since the inflamed area such as the tumor environment, is known as decreased $\mathrm{pH}$, we anticipated an increase in their antioxidant capacity by the exposure of TEMPO moiety due to collapsed $\mathrm{RNP}^{\mathrm{N}}$ (Figure $2 \mathrm{~b}, \mathrm{c}$ ). This means that both $\mathrm{pH}$-insensitive RNPO and $\mathrm{pH}$-sensitive $\mathrm{RNP}^{\mathrm{N}}$ will remain intact as a nano-sized self-assembling structure in the blood ( $\mathrm{pH}$ 7.4). In contrast, under a low $\mathrm{pH}$ environment, e.g., cancer, only $\mathrm{pH}$-sensitive $\mathrm{RNP}^{\mathrm{N}}$ will collapse into individual polymers and show higher ROS scavenging potential than its intact micelle structure and $\mathrm{RNP}^{\mathrm{O}}$ [78].

(a)
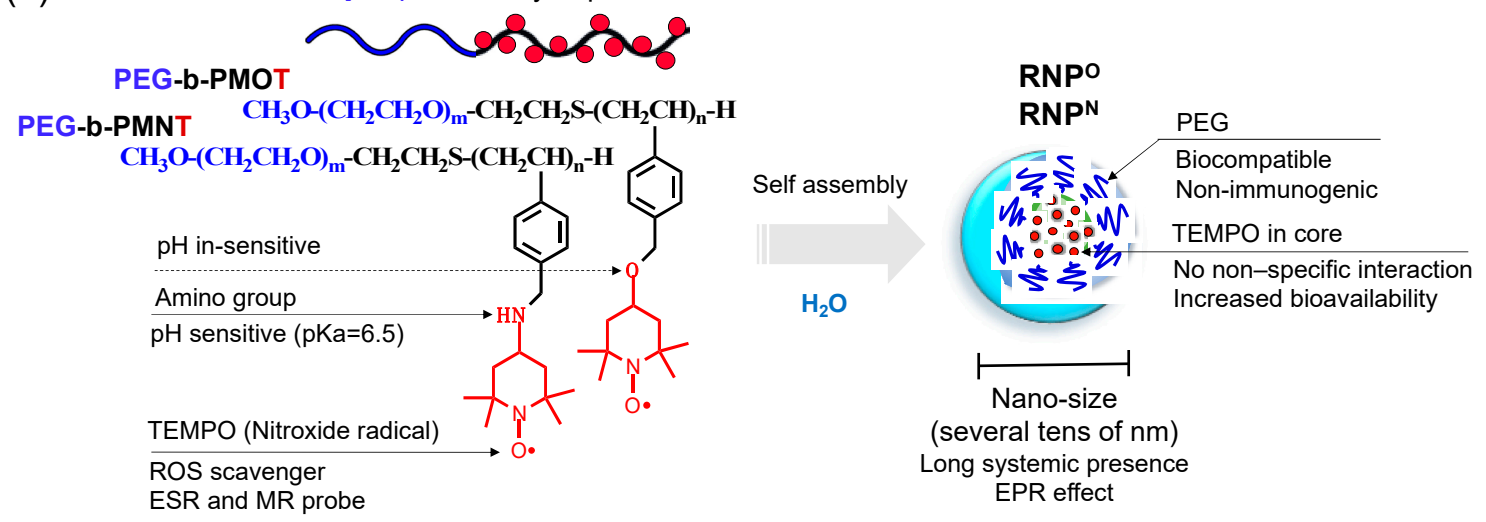

(b)

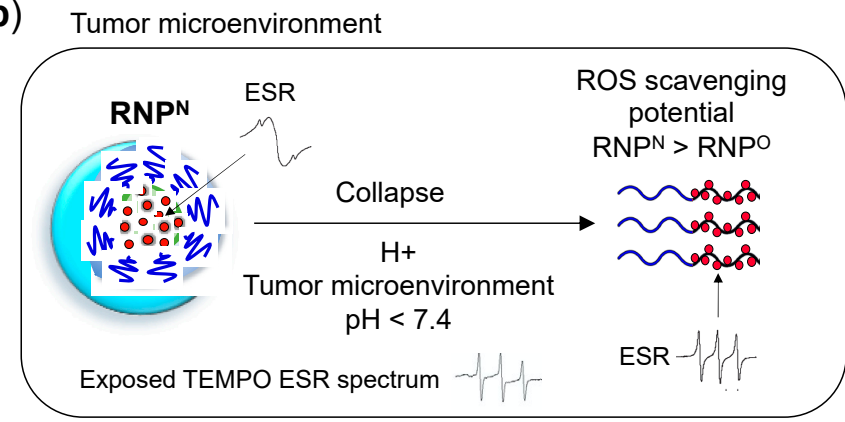

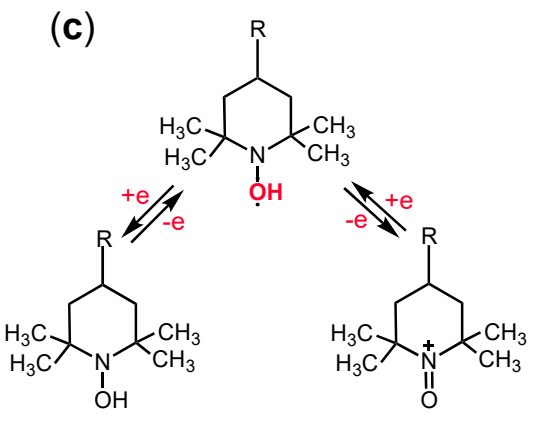

Figure 2. (a) Design and structure of antioxidant amphiphilic block copolymers, PEG- $b$-PMOT and PEG- $b$-PMNT, which self-assembles in aqueous media to form nano-sized micelles: $\mathrm{pH}$-insensitive $\mathrm{RNP}^{\mathrm{O}}$ and $\mathrm{pH}$-sensitive $\mathrm{RNP}^{\mathrm{N}}$, respectively, used for cancer therapy. (b) Illustration showcasing $\mathrm{pH}$-sensitive characteristic of $\mathrm{RNP}^{\mathrm{N}}$ in the diseased environment (tumor); the amino groups of antioxidant TEMPO moieties in the copolymer (pKa 6.5) is protonated under the low $\mathrm{pH}$ in the tumor environment, leading to collapse of $\mathrm{RNP}^{\mathrm{N}}$ micelle, which enhances its $\mathrm{ROS}$ scavenging potential than $\mathrm{pH}$-insensitive $\mathrm{RNP}^{\mathrm{O}}$. The exposed radical of TEMPO can be detected by Electron Spin Resonance (ESR) as sharp triplet peaks, but when it is in the core of stable $\mathrm{RNP}^{\mathrm{N}}$, the ESR signal of TEMPO broadens. At low $\mathrm{pH}$, due to disassembly of RNPN , TEMPO radical is exposed and displays characteristic sharp triplet peaks of TEMPO. This ESR sensitive characteristic is essential for the pharmacokinetics studies of RNPs. (c) Reduction and oxidization reaction equations of TEMPO. 
Following are the characteristics of RNPs validating its suitability for their use in in vivo applications.

i. Structure: RNP, a polymeric micelle made of amphipathic block copolymers, can stably disperse in in vivo harsh conditions due to the entanglement of hydrophobic segments in its core (Figure 2a) [79]. It is reported that PEG imparts biocompatible characteristic to nanoparticle by inhibiting electrostatic and hydrophobic interactions with proteins and cells sterically, thereby increasing the stability of nanoparticle [80]. Unpaired radical in TEMPO is stable by preventing the coupling with each other due to the protection by four methyl groups surrounding it. However, since ROS are small molecular radical species, they rapidly react with TEMPO's nitroxide radical. Although TEMPO is a highly reactive radical, it is conjugated via covalent linkage in the nanoparticle core; hence, non-specific interaction like LMW TEMPOL can be avoided upon administration. These characteristics potentially improve their accumulation in the target site via the EPR effect, which increases their therapeutic effects and prevents their premature renal excretion.

ii. Size: Core-shell type polymer micelles with several tens of nanometer in size (20-50 nm) ensures efficient accumulation in target intestinal mucosa (oral administration; colon cancer) or tumor vicinity (intravenous administration: breast cancer), additionally supported by the EPR effect $[70,81,82]$. It should be noted that the size range of RNP used in various anti-cancer studies, were small enough to prevent activation of the phagocytic system ( $\leq 100 \mathrm{~nm}$ cutoff size). Conversely, RNPs were large enough to evade rapid renal clearance ( $\geq 5.5 \mathrm{~nm}$ cutoff size) $[83,84]$.

iii. Stability: Dynamic light scattering studies confirmed that $\mathrm{RNP}^{\mathrm{O}}$ is stable under various $\mathrm{pH} 4-8.5$, whereas $\mathrm{pH}$-sensitive $\mathrm{RNP}^{\mathrm{N}}$ was stable at $\mathrm{pH} 7.4$ but decreased with a decrease in $\mathrm{pH}$, confirming its collapse at low $\mathrm{pH}$ (diseased condition; tumor) (Figure 3a). Nonetheless, both the micelles maintained structural integrity at physiological pH 7.4, confirming the structural stability in the blood [77]. Furthermore, in ex vivo spiking experiments, we demonstrated that RNP do not internalize in the blood cells and prevents blood cell aggregation on the glass beads, which was in sharp contrast to TEMPOL (Figure 3b,c) [85]. This inert characteristic of RNPs with blood is extremely important for the systemic administration of nanoparticles.

iv. ESR active properties: ESR measurement shows a characteristics sharp triplet peak of the exposed TEMPO radical (an interaction between ${ }^{14} \mathrm{~N}$ nuclei and the unpaired electron), but when confined in the core of RNP, the ESR signal of TEMPO broadens at the same magnetic field, due to restricted mobility of the radicals in RNP's solid core (Figure 2b) [75]. Due to this characteristic, it is very convenient to confirm the integrity and collapse of RNP and localization of RNPs for the pharmacokinetics studies.

RNPs have shown remarkable therapeutic effects with characteristics mentioned above than LMW antioxidant, TEMPOL, in various oxidative stress-related diseases such as cancer, colitis, cerebral hemorrhage, acute renal injury, Alzheimer's disease and so on, attributed to their favorable pharmacokinetic properties [86].

\subsection{Safety of RNPS}

It was previously reported that TEMPOL induces apoptosis by impairing the oxidative phosphorylation and targeting complex I of the respiratory system affecting mitochondrial membrane potential in HL-60 cells [87]. In our studies, similar findings confirmed that LMW TEMPOL exerts adverse effects in various models, potentially caused due to its facile internalization into the normal cells and disruption of critical redox balance attributed to highly reactive nitroxide radicals. On the other hand, due to their higher molecular weight (ca. $10 \mathrm{kDa}$ ) and the self-assembling size (ca. 20-50 nm), RNPs avoid internalization into the normal cells and prevents disruption of their redox homeostasis [85,88]. For instance, as shown in Figure $3 \mathrm{~d}$, when zebrafish were maintained in $3 \mathrm{mM}$ and $30 \mathrm{mM}$ TEMPOL solution, they died within five days of TEMPOL addition. In contrast, in $30 \mathrm{mM}$ 
$\mathrm{RNP}^{\mathrm{O}}$-treated group, more than $95 \%$ of zebrafish survived at day 5, confirming low toxicity of RNPs. This safety was further confirmed by the negligible damage to zebrafish mitochondria in the RNP-treated group, while the elevated damage was observed in the TEMPOL-treated group (Figure 3e) [88]. In the ex vivo blood spiking experiment, we also confirmed that RNPs do not interact and internalize into the healthy blood cells (Figure 3c) and disrupt mitochondrial membrane potential of blood cells, which was in sharp contrast to TEMPOL [85]. In addition, the median lethal dose $\left(\mathrm{LD}_{50}\right)$ of TEMPOL in $\mathrm{C} 3 \mathrm{H}$ mice was $341 \mathrm{mg} / \mathrm{kg}$ through intravenous administration, whereas for $\mathrm{RNP}^{\mathrm{N}}, \mathrm{LD}_{50}$ value was higher than $600 \mathrm{mg} / \mathrm{kg}(960 \mathrm{mmol} \mathrm{N} / \mathrm{kg})$ in ICR mice [77,89]. Extremely low toxicity of RNPs than LMW TEMPOL confirms that the confinement of conjugated TEMPO in the core of several tens of nanometer-sized self-assembled nanoparticles is necessary to avoid off-target effects and attain enhanced accumulation in the target tissue, leading to higher therapeutic effect.

(a)

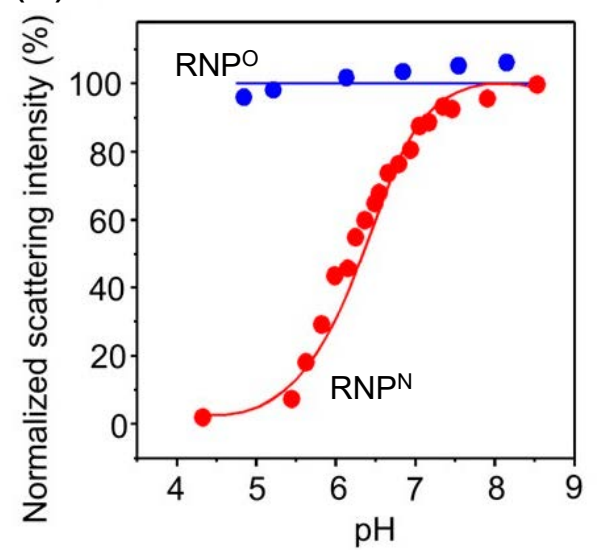

(b)

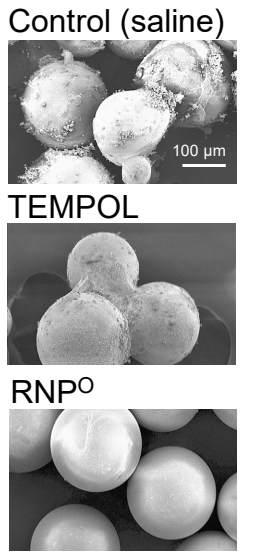

(c) Rat blood cells

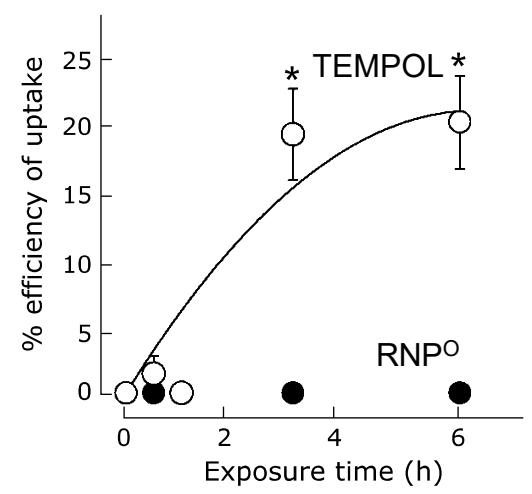

(d)

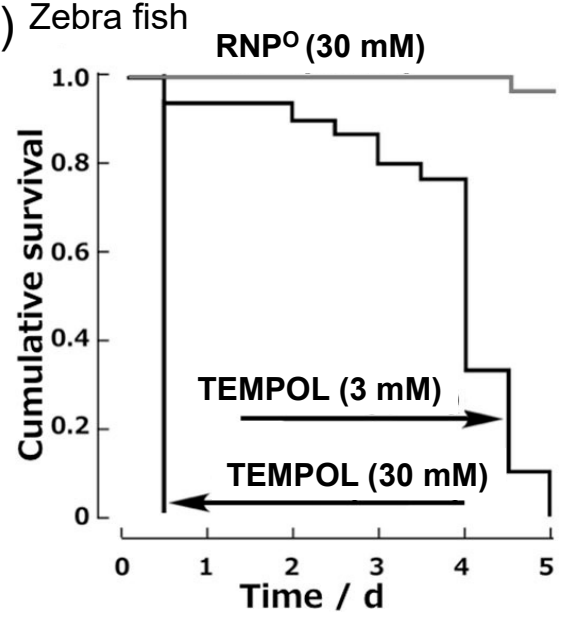

(e)

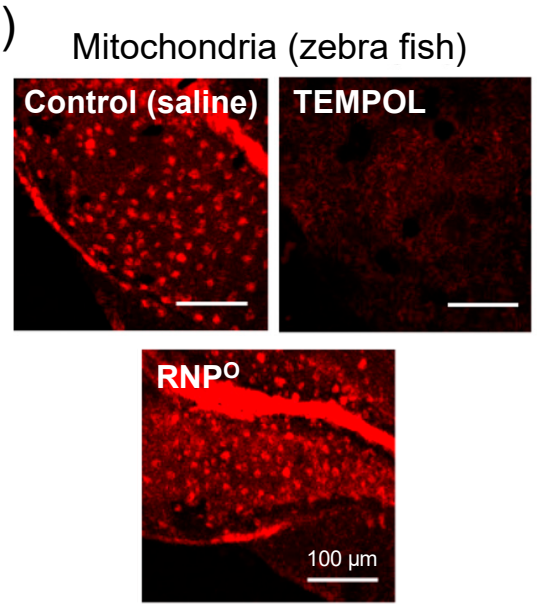

Figure 3. Characterization and non-toxicity of RNPs. (a) Laser light scattering intensity of RNPO and RNPN as a function of $\mathrm{pH}$, assessed by dynamic light scattering [77]. (b) SEM images of glass beads spiked in rat whole blood with saline, TEMPOL, and RNPO (5 mM) for $30 \mathrm{~min}$ [85]. (c) The cellular uptake of TEMPOL and RNPO by rat whole blood cells evaluated by ESR [85]. (d) Cumulative survival of zebrafish embryo maintained in $\mathrm{RNP}^{\mathrm{O}}$ (30 mM) and TEMPOL (3 and $30 \mathrm{mM}$ ) [88]. (e) Microscopic images of the mitochondrial damage in zebrafish larva after $12 \mathrm{~h}$ of treatment, assessed by mitotracker and analyzed using a fluorescent confocal microscope system, scale bar $100 \mu \mathrm{m}$ [88]. ${ }^{*} p<0.05$ was considered significant. This figure is reproduced with permission from References [77,85,88]. Copyright 2011, Elsevier; Copyright 2014, JCBN; Copyright 2016, American Chemical Society. 


\subsection{Pharmacokinetic Properties of RNPs}

TEMPOL, a low molecular weight compound with an exposed reactive nitroxide radical, has poor pharmacokinetics, which excretes rapidly after the administration. Thus, to suppress the rapid excretion and avoid the unwanted adverse effects, we covalently conjugated TEMPO to the amphiphilic block copolymer backbone with self-assembling characteristics, forming nanoparticle with several tends nanometer in size and accumulation tendency in the target inflamed site, such as a tumor. We confirmed this improvement of the pharmacokinetic property of RNPs in the renal ischemia-reperfusion induced acute kidney injury mice model [77]. In this study, an equal dose of $\mathrm{RNP}^{\mathrm{O}}, \mathrm{RNP}^{\mathrm{N}}$, and TEMPOL (TEMPO: $75 \mathrm{mmol} / \mathrm{kg}$ ) were administered to ICR mice, after which TEMPO concentration was measured in the blood and kidneys by ESR. As shown in Figure 4a, TEMPOL cleared from the blood within $0.1 \mathrm{~h}$ of the administration, whereas $\mathrm{RNPO}$ and $\mathrm{RNP}^{\mathrm{N}}$ remained in the blood for more than $10 \mathrm{~h}$. In the injured kidney (Figure $4 \mathrm{~b}$ ), TEMPOL was excreted within $0.5 \mathrm{~h}$ of administration, whereas $\mathrm{RNP}^{\mathrm{O}}$ remained for $24 \mathrm{~h}$ and $\mathrm{RNP}^{\mathrm{N}}$ managed to stay more than $10 \mathrm{~h}$. This data confirmed that the kidneys, a major clearance organ, do not remove the RNPs as fast as LMW TEMPO due to their suitable structure and size. It is known that after reperfusion in the ischemic kidney, ROS level is significantly elevated, causing inflammation and decreased $\mathrm{pH}$ via acidosis [90]. As shown in Figure 4a, RNPO and $\mathrm{RNP}^{\mathrm{N}}$ in the blood are observed as intact micelles, assessed through a broader ESR signal than TEMPOL radical. In kidneys with acidic lesions, $\mathrm{RNP}^{\mathrm{O}}$ integrity remains intact. In contrast, the ESR signal of $\mathrm{RNP}^{\mathrm{N}}$ resembles to that of free TEMPOL radical (Figure $4 \mathrm{~b}$ ), implying the micelle collapse in response to acidic $\mathrm{pH}$ in the injured kidneys. This data confirms the $\mathrm{pH}$ sensitivity of RNPs in the diseased condition and their stability during systemic circulation compared to LMW TEMPOL.

We also confirmed the pharmacokinetics of $\mathrm{RNP}^{\mathrm{N}}$ in a mice model of colon cancer, by intravenous administration of RNP ${ }^{\mathrm{N}}$ and TEMPOL (40 mg/ $\mathrm{kg}$ of TEMPO), which was assessed by ESR measurement [82]. As shown in Figure $4 \mathrm{c}, \mathrm{RNP}^{\mathrm{N}}$ remains in the blood even until $24 \mathrm{~h}$ (AUC, 769.49). In contrast, the LMW TEMPOL signal decreases drastically within $2 \mathrm{~h}$ (AUC, 19.2), which may be attributed to their diffusion into the normal cells and preferential renal clearance. The total accumulation of RNP in the tumor tissues (AUC, 39.6) was at least 6-7 fold higher than LMW-TEMPOL (AUC, 6.5). After $24 \mathrm{~h}$ of administration, $\mathrm{RNP}^{\mathrm{N}}$ in tumor tissues was $8-9$ fold higher (3.3\% ID/g tumor tissue) compared to TEMPOL ( $0.4 \%$ ID/g tumor tissue) (Figure $4 \mathrm{~d}$ ). Interestingly, $\mathrm{RNP}^{\mathrm{N}}$ remained intact as micelle in the blood and collapsed in a low $\mathrm{pH}$ tumor area, as assessed by ESR spectra. The reports mentioned above confirm that the covalent conjugation of TEMPO with amphiphilic copolymer and their self-assembling core-shell structure significantly suppresses their adverse effect and prolongs their presence in the systemic circulation. Due to the long blood circulation of RNP, they gradually accumulate in the target site via the EPR effect with negligible diffusion in the normal cells compared to LMW highly reactive TEMPO radical. With such favorable pharmacokinetics and negligible toxicity compared to LMW antioxidants, we evaluated the therapeutic efficacy of RNPs in various cancer models. The next section will discuss the application of RNPs in breast cancer, colon cancer, prostate cancer, and resistant epidermoid cancers as stand-alone or as adjuvants with conventional anti-cancer drugs. 
(a)

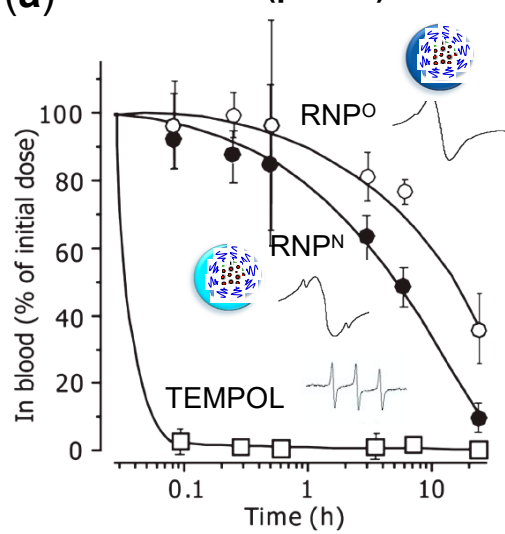

(c)

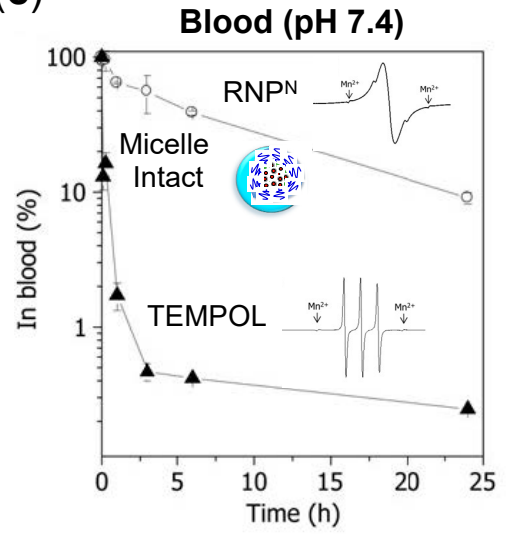

(b) Injured kidney $(\mathrm{pH}<7.4)$

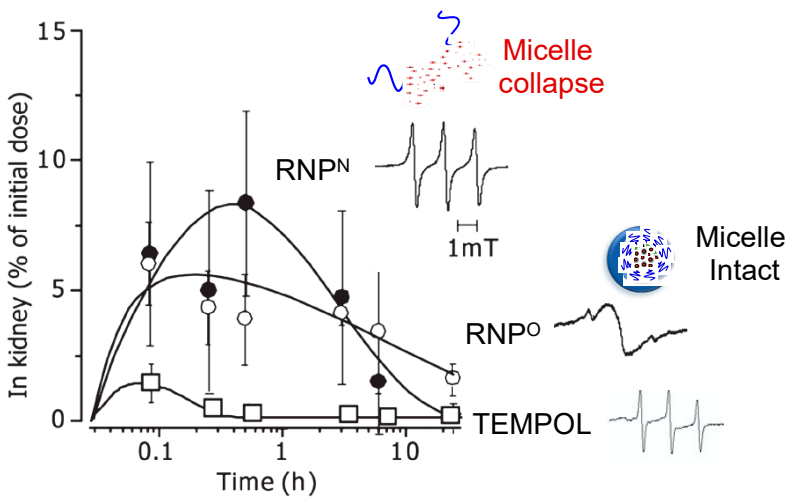

(d)

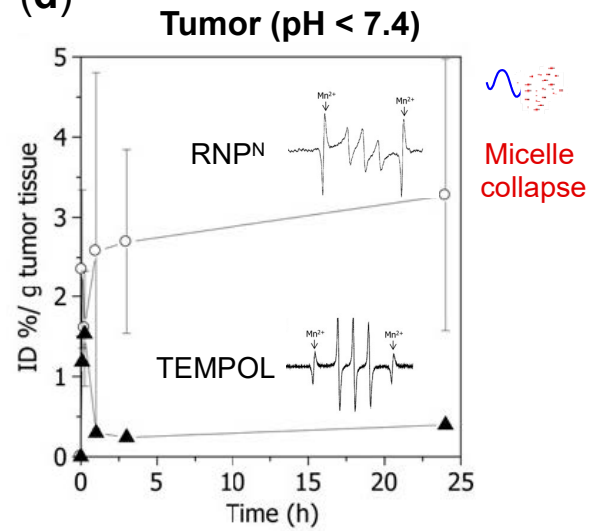

Figure 4. (top) Pharmacokinetic property of $\mathrm{RNP}^{\mathrm{N}}$ and $\mathrm{RNP}^{\mathrm{O}}$ in the blood and diseased organs. Time profile changes in the concentration of $\mathrm{RNP}^{\mathrm{O}}, \mathrm{RNP}^{\mathrm{N}}$, and TEMPOL; (a) blood and (b) injured kidney, after intravenous administration (75 mmol/ $\mathrm{kg}$ of TEMPO concentration) in a renal ischemia-reperfusion induced acute kidney injury mice model $[75,77]$. The graph also displays ESR spectra of TEMPO radical of RNPs and TEMPOL. The ESR spectra of RNPs are broad under the physiological pH conditions (7.4), confirming their micelle integrity, in contrast with the sharp triplet peak of free TEMPOL. Under the decreased $\mathrm{pH}$ conditions, a typical diseased state, the $\mathrm{pH}$-sensitive $\mathrm{RNP}^{\mathrm{N}}$ group shows sharp triplet ESR signals, indicating the micelle collapse as compared to $\mathrm{pH}$-insensitive $\mathrm{RNP}^{\mathrm{O}}$, whose micelle integrity is unaffected. (bottom). Biodistribution of $\mathrm{RNP}^{\mathrm{N}}$ and TEMPOL in a colon tumor (C-26 colon cancer cell line) bearing mice after intravenous administration with $40 \mathrm{mg} / \mathrm{kg}$ of TEMPO concentration; (c) blood and (d) tumor [82]. These data confirm that RNP ${ }^{\mathrm{N}}$ is stable in the blood (broad ESR signal), while it is collapsed in the tumor environment due to the reduced pH (sharp ESR peaks). This figure is reproduced with permission from References [75,77,82]. Copyright 2011, Elsevier; Copyright 2014, WILEY-VCH Verlag GmbH \& Co. KGaA, Weinheim; Copyright, 2013 Elsevier B.V.

\subsection{RNPs for Cancer Therapy}

\subsubsection{RNPs Inhibit the Tumorigenic Potential of Triple-Negative Breast Cancer}

As stated above, we have succeeded in developing novel self-assembling antioxidants, which is less toxic and do not cause intracellular disturbance to the redox homeostasis of the normal cells. With these characteristics, the functionality of RNP as an anti-cancer drug was investigated in breast cancer. Breast cancer is the most common cancer occurring in women worldwide, with 2 million new cases diagnosed in 2018 (American Institute for Cancer Research). Due to the increase in the mortality rate of breast cancer patients, an alternative treatment is needed [91]. It was reported that breast cancer patients have significantly higher ROS levels such as superoxide and hydrogen peroxide in plasma, which correlated with the severity of the disease and altered antioxidant enzyme levels such as SOD in the tumor cells $[92,93]$. Copper, a potent oxidant, was also significantly elevated in the serum and tumor of cancer patients than the healthy subjects [94]. It is reported that copper 
induces HIF-1 $\alpha$ and VEGF expression through the activation of the EGFR/ERK/c-fos transduction pathway promoting breast tumor angiogenesis and progression, which were reversed upon the addition of copper chelating agent and antioxidant NAC [95]. Menon et al. reported that the loss of redox control of the cell cycle might contribute to the aberrant proliferation of breast cancer cells [96]. Another report suggested that sublethal oxidative stress by $\mathrm{H}_{2} \mathrm{O}_{2}$ /hypoxanthine and xanthine oxidase inhibited tumor cell adhesion to laminin and fibronectin and enhanced lung tumors of murine mammary carcinoma in an experimental metastasis model [97]. Based on these critical roles of oxidative stress in breast cancer survival, we evaluated the efficacy of our antioxidant self-assembled nanoparticle in a breast cancer model.

We investigated the anti-tumor and anti-metastatic effects of $\mathrm{RNP}^{\mathrm{O}}$ and $\mathrm{RNP}^{\mathrm{N}}$ using the triple-negative breast cancer cell line, MDA-MB231 (Figure 5a) [98,99]. Colony-forming assay was carried out in vitro using breast cancer cell lines, metastatic MDA-MB-231 and non-metastatic MCF-7. Treatment with $\mathrm{IC}_{50}$ values (RNPO; MDA-MB-231 $=2.20 \mathrm{mM}$, MCF-7 = $1.14 \mathrm{mM}, \mathrm{RNP}^{\mathrm{N}}$; MDA-MB-231 $=3.00 \mathrm{mM}$, MCF-7 = $1.08 \mathrm{mM}$, and TEMPOL; MDA-MB-231 $=0.56 \mathrm{mM}, \mathrm{MCF}-7=0.46 \mathrm{mM})$, revealed that $\mathrm{RNP}^{\mathrm{N}}$ showed the highest inhibition of colony-forming potential, followed by $\mathrm{RNP}^{\mathrm{O}}$ and TEMPOL (Figure $5 \mathrm{~b}$ ). This data clearly indicates that the TEMPO-based antioxidants, $\mathrm{RNP}^{\mathrm{N}}$ and $\mathrm{RNP} \mathrm{O}^{\mathrm{O}}$, exerted a long-term inhibitory effect on the breast cancer cell growth regardless of their metastasis tendency than LMW TEMPOL with less toxicity. We next investigated in vivo efficacy of RNPs in a mouse xenograft model of breast cancer cell line, MDA-MB231. Intravenous administration of $\mathrm{RNPO}^{\mathrm{O}}$ and $\mathrm{RNP}^{\mathrm{N}}$ (TEMPO; $74.13 \mathrm{mg} / \mathrm{kg}$, five times, three days interval) showed a significantly decreased tumor growth than the untreated control and TEMPOL (Figure 5c). The tumor growth profile graph clearly shows that RNPs inhibit tumor growth much higher than TEMPOL and comparable to the conventional anti-cancer drug paclitaxel ( $10 \mathrm{mg} / \mathrm{kg}$, five times, three days interval), indicating the importance of ROS scavenging in breast cancer treatments. We also confirmed that RNPs showed anti-metastatic effect by inhibiting the growth of MDA-MB231 lung tumors in an experimental metastasis model, which was higher than TEMPOL (TEMPO: $18.53 \mathrm{mg} / \mathrm{kg} / \mathrm{mouse}, 10$ times, 3 days interval) and comparable to paclitaxel ( $5 \mathrm{mg} / \mathrm{kg} /$ mouse, 10 times, 3 days interval) (Figure $5 \mathrm{~d}$ ). This decrease in tumor size exerted by RNPs corroborated with decreased tumor ROS, which was negligibly reduced in the TEMPOL-treated group (Figure 5e).

NF-kB is a redox-sensitive transcriptional factor which regulates expression of metallomatrix protease (MMP-2) and $\alpha 2,6$-sialyltransferae. MMPs function to degrade the extracellular matrix proteins and has been correlated with poor clinical outcome in breast cancer patients $[10,100] . \alpha 2,6$-sialyltransferae catalyzes the addition of sialic acid to terminal oligosaccharides attached on the lipid or protein moieties of the tumor surface, which contributes to tumorigenesis, progression, and metastasis [101]. As shown in Figure 5f,g, both RNPs downregulate the expression of NF-kB, MMP-2, and $\alpha 2,6$-sialyltransferae in MDA-MB231 tumors and cells, suggesting the mechanism of anti-tumor and anti-metastatic effect of RNPs. It should be noted that such high efficacy of our antioxidant nanoparticle was achieved with negligible adverse effects on the kidneys and livers, in contrast to LMW TEMPOL, and paclitaxel-treated group (Figure $5 \mathrm{~h}, \mathrm{i}$ ). These reports suggest that our RNPs alone are more effective in inhibiting ROS-mediated tumorigenesis and metastasis of breast cancer as compared to LMW antioxidants. 
(a)

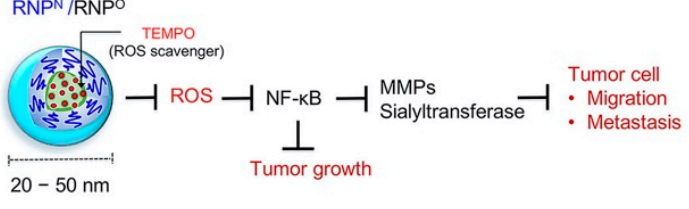

(b) Control RNPO RNPN TEMPOL

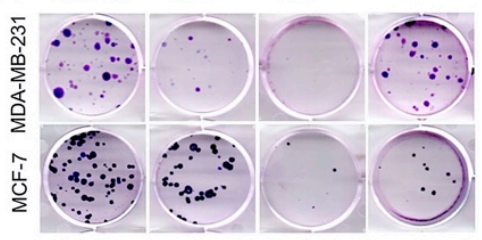

(c)

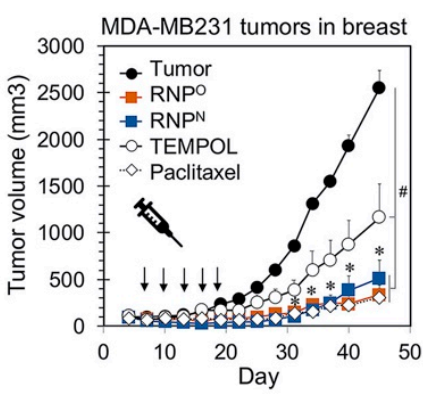

(d) MDA-MB231 lung tumors

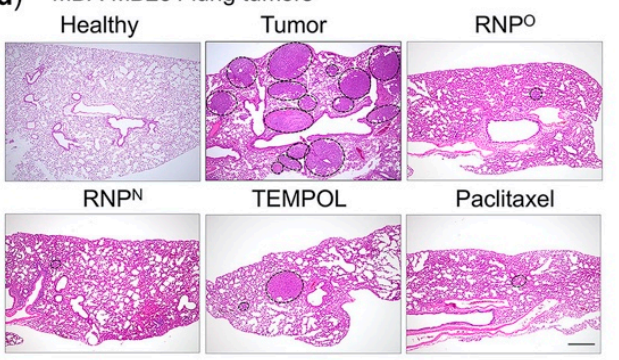

(e)

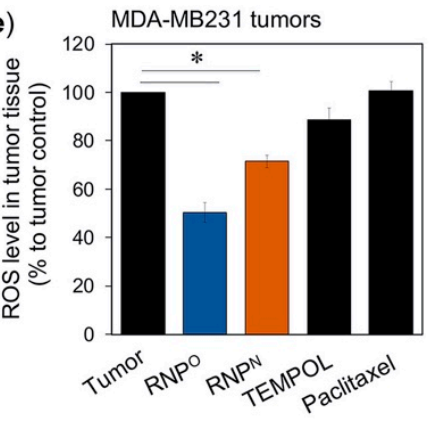

(f) MDA-MB231 tumors

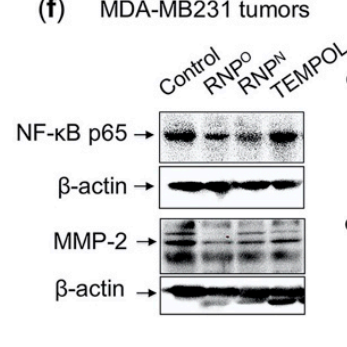

(g) MDA-MB231 cell line

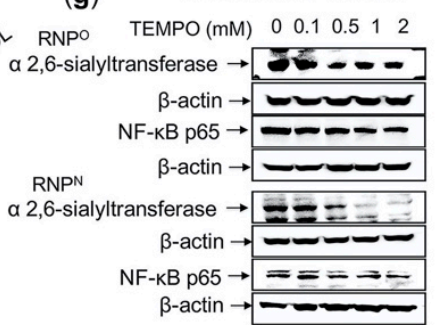

(h)

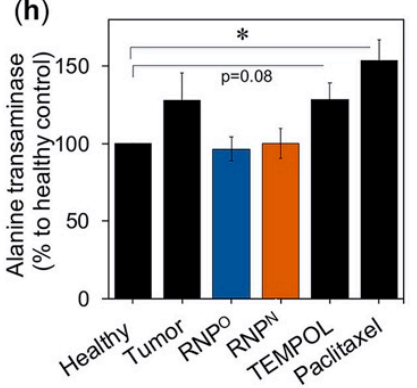

(i)

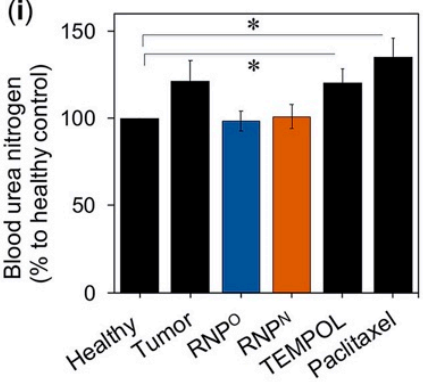

Figure 5. $\mathrm{RNP}^{\mathrm{N}}$ and $\mathrm{RNP}$ inhibits the growth, proliferation, and metastatic potential of triple-negative breast cancer, MDA-MB231, with negligible adverse effects. (a) Schematic illustration of ROS-reduction mediated anti-tumor and antimetastatic effect of RNPs. (b) Inhibition of colony-forming potential of breast cancer cell lines, MDA-MB231 and MCF-7 by $\mathrm{RNP}^{\mathrm{N}}, \mathrm{RNPO}^{\mathrm{O}}$, and TEMPOL (IC 50 value, 48 h). (c) Tumor growth profile of breast cancer cell line (MDA-MB231) in the mice xenograft model, intravenously administered with $\mathrm{RNP}^{\mathrm{N}}$, RNPO , TEMPOL (74.13 mg/kg of TEMPO concentration), and conventional anti-cancer drug paclitaxel $(10 \mathrm{mg} / \mathrm{kg})$. (d) Representative histopathological $\mathrm{H}$ and E-stained lung sections of MDA-MB231 experimental metastasis model mice, intravenously administered with $\mathrm{RNP}^{\mathrm{N}}$, RNPO , TEMPOL $(18.5 \mathrm{mg} / \mathrm{kg}$ of TEMPO concentration) and paclitaxel $(5 \mathrm{mg} / \mathrm{kg}$ ). The encircled areas are representing MDA-MB231 tumors. Scale bar 500 $\mu \mathrm{m}$. (e) ROS scavenging potential of RNPs in MDA-MB231 tumors detected by dihydroethidium compared to the untreated tumor as $100 \%$. (f) Downregulation of MMP-2 and NF-kB expression by RNPs in MDA-MB231 tumors, as assessed by immunoblotting. (g) The ability of RNPs to suppress the expression of NF-kB and sialyltransferase, important enzymes assisting the metastasis of MDA-MB231 cell line, as assessed by immunoblotting [99]. Non-toxicity of RNPs as compared to LMW TEMPOL and paclitaxel after their intravenous administration, confirmed by liver and kidney damage markers: (h) alanine transaminase and (i) blood urea nitrogen, respectively. ${ }^{*} p<0.05$ was considered significant [98]. This figure is reproduced with permission from References [98,99]. Copyright 2017, Elsevier Ltd.; Copyright 2018, Elsevier Ltd. 


\subsubsection{RNPs Inhibit the Tumor Growth and Progression of Colitis-Associated Cancer}

An increase in oxidative stress and oxidative cellular damage promoting carcinogenesis has been observed in inflammatory bowel disease patients [102,103]. Ulcerative colitis (an inflammatory bowel disease) associated with colon cancer (CAC) is the third most common malignancy and one of the major causes of cancer-related death [104]. With these facts, we tested the efficacy of RNPs to suppress the oxidative stress-mediated tumor formation in the mice colon [105]. The pharmacokinetics of $\mathrm{RNP}^{\mathrm{O}}$ by free drinking confirmed that $\mathrm{RNPO}^{\mathrm{O}}$ accumulates in the colon with negligible internalization in the blood (ESR measurement) (Figure 6a). The localization of rhodamine-labeled $\mathrm{RNPO}^{\mathrm{O}}$ further validated the colon accumulation of $\mathrm{RNPO}^{\mathrm{O}}$ after $4 \mathrm{~h}$ of administration. As shown in Figure $6 \mathrm{~b}$, the rhodamine-labeled $\mathrm{RNP}^{\mathrm{O}}$ was strongly observed in the colon, especially in the colon's mucosa area. In contrast, no fluorescent was observed in rhodamine administered group, as it was excreted out sooner than $\mathrm{RNP}^{\mathrm{O}}$. This data confirmed that LMW antioxidants might not be suitable for CAC treatment due to their poor retentivity in the colon [106]. The effect of RNPs on colon cancer was investigated by a CAC mice model, which was prepared by intraperitoneal injection with azoxymethane (AOM) $(10 \mathrm{mg} / \mathrm{kg}$ body weight) followed by two cycles of 7d-treatment of $3 \%$ dextran sodium sulfate (DSS) (Figure 6c). As shown in Figure 6d,e, the oral administration of $\mathrm{RNP}^{\mathrm{O}}$ during DSS treatment significantly suppressed the tumor formation in the colon, which was confirmed by endoscopy and $\mathrm{H}$ and $\mathrm{E}$ stained colon tissues. In the RNP-treated group, no change in the body weight was observed compared to AOM/DSS control, which was significantly reduced during DSS treatment (data not shown).

It is worth noting that such an effect of $\mathrm{RNP}^{\mathrm{O}}$ was supported with decreased colitis disease index and pro-inflammatory cytokine interferon-gamma (IFN- $\gamma$ ). These results indicate the potential of $\mathrm{RNP}^{\mathrm{O}}$ to reduce colitis-induced inflammation, which is a major factor for the induction of colon cancer. Ad libitum drinking of $\mathrm{RNP}^{\mathrm{O}}$ solution $(5 \mathrm{mg} / \mathrm{mL})$ after AOM and DSS treatment also significantly suppressed the tumor formation in the colon as assessed by endoscopy and histology (Figure $6 \mathrm{f}-\mathrm{h}$ ). These reports confirmed that $\mathrm{RNPO}^{\mathrm{O}}$ is an effective and suitable nano-antioxidant for the treatment of colon cancer.

4.4.3. Synergistic Effects of RNP and Fibrinolytic Tissue Plasminogen Activator for Colon Cancer Therapy

It is well known that the efficacy of drugs to inhibit tumor growth depends on whether the drug has sufficiently reached the target site or not, which depends on the blood perfusion status within the tumor vessels [107]. The tumor microenvironment is complex, comprising of extracellular matrix (ECM) components such as fibrin, elastin, laminin, collagen, platelet aggregation, etc. The ECM is known to obstruct the blood flow and perfusion to the tumor areas, limiting the effective delivery of drugs, contributing to inadequate drug response, and promoting drug resistance [108].

Degradation of ECM components from the tumor environment is a robust strategy to improve vascularization and blood supply to the tumors. Fibrinolytic tissue plasminogen activator (t-PA), is a member of the serine protease family, physiologically involved in the matrix regulation and homeostasis of the blood coagulation/fibrinolysis [109]. Zhang et al. reported on the use of t-PA for modulating the tumor microenvironment to improve the delivery efficiency of anti-cancer drug to the target site [110]. 
(a)

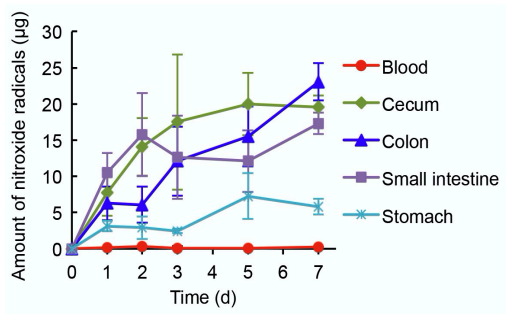

(b)

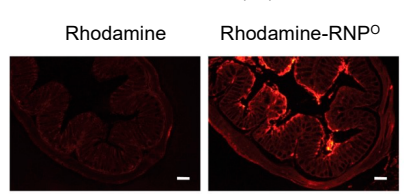

(c) Oral gavage

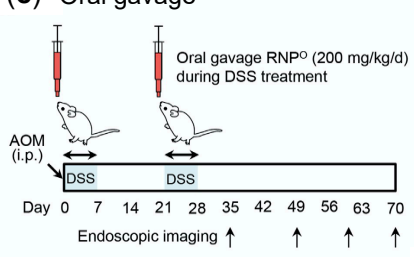

(d) $\rightarrow$ AOM/DSS

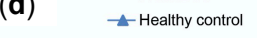

$\rightarrow$ AOMIDSS +RNP

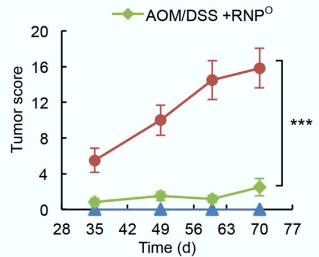

(e) Healthy control AOM/DSS

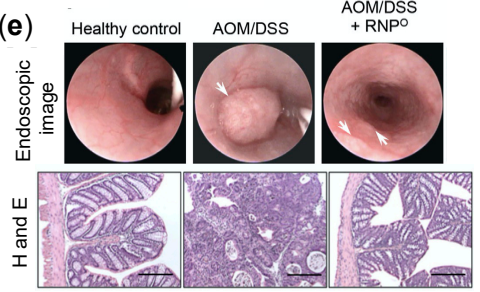

(f) Free drinking

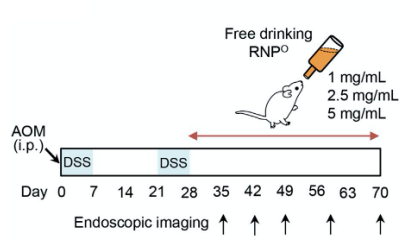

(g)

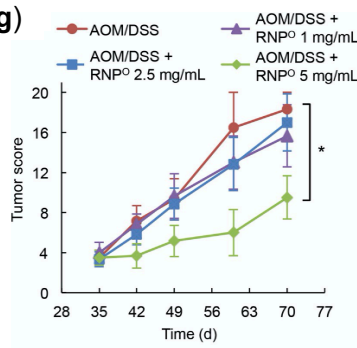

(h)

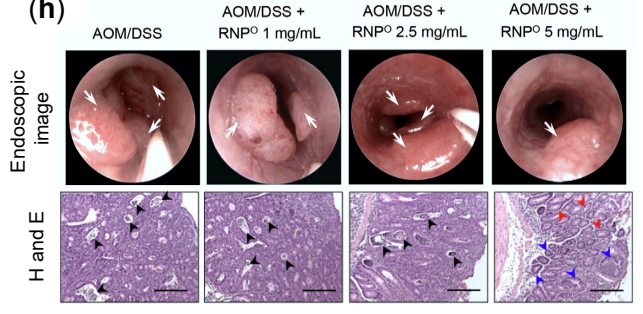

Figure 6. Anti-tumor effect of $\mathrm{RNP}^{\mathrm{O}}$ in colitis-induced colon cancer (CAC) model. (a) Accumulation of $\mathrm{RNP}^{\mathrm{O}}$ in the gastrointestinal tract by ad libitum drinking, assessed by ESR measurement [105]. (b) Localization of rhodamine-labeled $\mathrm{RNP}^{\mathrm{O}}$ (rhodamine- $\mathrm{RNP} \mathrm{O}^{\mathrm{O}}$ ) in the colon section, $4 \mathrm{~h}$ after the oral administration with $5 \mathrm{mg} / \mathrm{mL}$ of rhodamine- $\mathrm{RNP}$ ( $(1 \mathrm{~mL})$, scale bar $200 \mu \mathrm{m}$ [106]. (c) The scheme showing anti-tumor effect (protective) of orally administered $\mathrm{RNPO}^{\mathrm{O}}$ in azoxymethane $(\mathrm{AOM})$ and dextran sodium sulfate (DSS) (AOM/CAC) induced colitis-associated cancer in mice. $\mathrm{RNP}^{\mathrm{O}}(200 \mathrm{mg} / \mathrm{kg} / \mathrm{d}) \mathrm{was}$ administered by oral gavage during the two weeks of the DSS treatment period. (d) $\mathrm{RNP}^{\mathrm{O}}$ inhibits the formation of colon tumor, confirmed by tumor score and assessed by endoscopy. (e) The endoscopic imaging of mice colon, displaying tumor shown by white arrows and $\mathrm{H}$ and E-stained colon tissues (scale bar $100 \mu \mathrm{m}$ ) at the experimental endpoint (day 70). (f) The scheme showing anti-tumor effect (therapeutic) of ad libitum drinking of $\mathrm{RNP}^{\mathrm{O}}$ in AOM/CAC-induced colitis-associated cancer in mice. $\operatorname{RNP}^{\mathrm{O}}(1,2.5$, and $5 \mathrm{mg} / \mathrm{mL})$ was available as ad libitum drinking after AOM/DSS treatment. (g) The therapeutic effect of $\mathrm{RNP}^{\mathrm{O}}$ to inhibit the formation of colon tumor as confirmed by tumor score, which was assessed by endoscopy. (h) The endoscopic imaging of mice colon, displaying tumor shown by white arrows and $\mathrm{H}$ and $\mathrm{E}$ stained colon tissues (scale bar $100 \mu \mathrm{m}$ ), at the experimental endpoint (day 70). Black arrows in $\mathrm{H}$ and $\mathrm{E}$ colon stained tissues indicate the necrotic cells surrounded by cancer cells, blue arrows indicate adenoma, and red arrows display normal crypts [105]. ${ }^{*} p<0.05$ was considered significant. This figure is reproduced with permission from References $[105,106]$. Copyright 2018, Elsevier Ltd.; Copyright 2012, AGA Institute (Elsevier publisher).

Because the half-life of the naked t-PA is extremely short $(<5 \mathrm{~min})$, continuous and invasive intravenous administrations are required to show their effectiveness [111]. In this line, we employed RNP as a new delivery platform for t-PA, which not only acts as DDS with favorable pharmacokinetics but also contributes to the anti-tumor effect through ROS scavenging characteristic (Figure 7a) [112,113]. t-PA@iRNP (hereafter " $i$ " in iRNP denotes the core composed of polyion complex) is a core-shell structured polyion complex (PIC) micelle consisting of three components: (i) ROS scavenging cationic PEG$b$-PMNT diblock amphiphilic copolymers, (ii) anionic poly (acrylic acid) (PAAc) and (iii) fibrinolytic t-PA (Figure 7a). We found that t-PA@iRNP retained their enzymatic activity after $2 \mathrm{~h}\left(\mathrm{t}_{1 / 2}=71 \mathrm{~min}\right)$ of intravenous administration, whereas the activity of naked t-PA decreased within $0.5 \mathrm{~h}\left(\mathrm{t}_{1 / 2}=8 \mathrm{~min}\right.$ ) (Figure $\left.7 \mathrm{~b}\right)$ [113]. The prolonged enzymatic activity of $\mathrm{t}$-PA@iRNP than naked t-PA is due to the stable encapsulation of t-PA in the iRNP matrix, which protected it from the enzymatic degradation. We have previously confirmed that $\mathrm{t}-$ 
PA@iRNP had almost no enzymatic activity under the physiological pH (7.4). On the other hand, upon decreasing the $\mathrm{pH}$, its enzymatic activity was significantly increased, indicating the $\mathrm{pH}$ responsive collapse of $\mathrm{t}-\mathrm{PA} @ \mathrm{i} \mathrm{RNP}$. Intravenous administration of t-PA@iRNP (t-PA; $0.04 \mathrm{mM}$ and iRNP; $5.3 \mathrm{mM}$ TEMPO, five times with interval of three days) to mouse xenograft model of C-26 colon cancer cell line, showed effective suppression of tumor growth as compared to control, t-PA@niRNP (no antioxidant capacity), naked t-PA, and iRNP, validating the synergistic effect of iRNP and t-PA (Figure 7c) [112]. Interestingly, iRNP alone also showed a significant anti-tumor effect on colon tumors. It should be noted that the pharmacokinetics of t-PA upon encapsulation by iRNP is favorably changed for in vivo application. This pattern can be seen in t-PA@niRNP, where a higher effect of t-PA could be observed when encapsulated in niRNP (no antioxidant capacity), than the naked t-PA itself, indicating the importance of delivery systems for the proteins (Figure 7c,d).

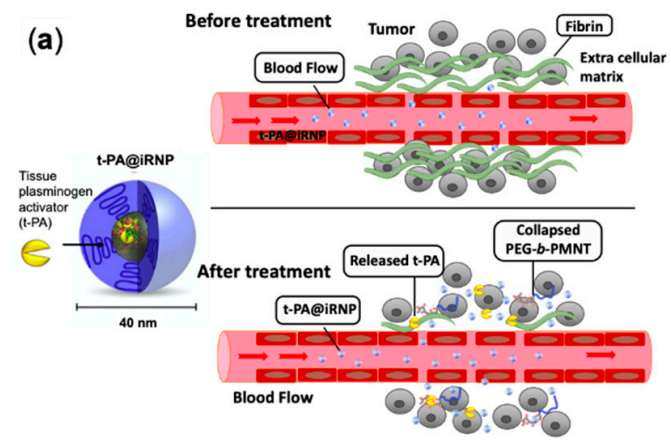

(b)

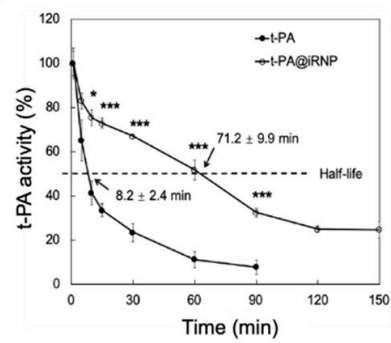

(c)

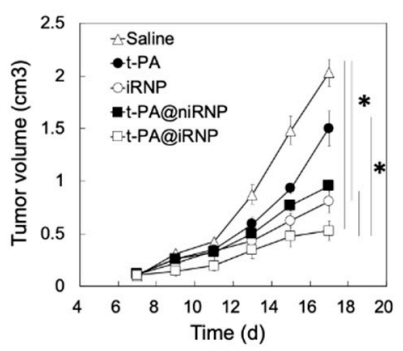

(d)

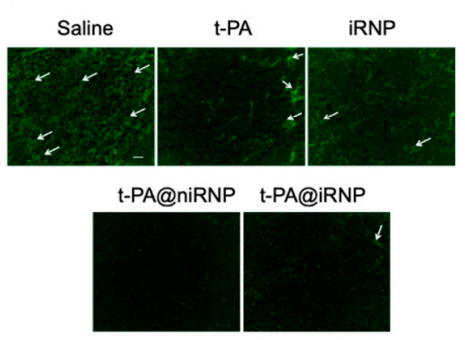

(e)

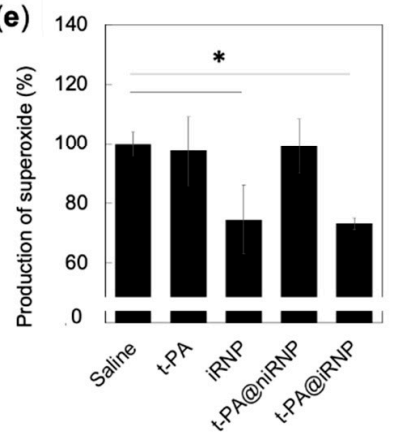

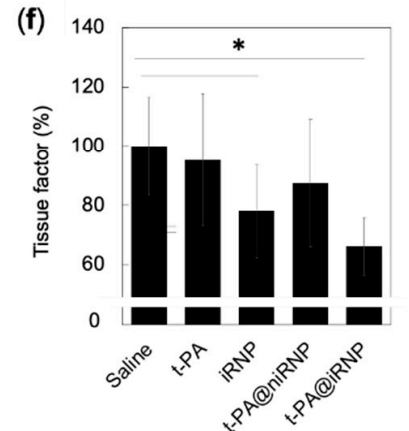

Figure 7. Anti-tumor effect of fibrinolytic tissue plasminogen activator installed in radical containing nanoparticles ( $\mathrm{t}$ PA@iRNP). (a) Schematic illustration of the delivery and therapeutic effect of t-PA@iRNP in tumors characterized by dense fibrin extracellular matrix [112]. (b) Ex vivo thrombolytic activity of t-PA enzyme, after intravenous administration in mice with equimolar dose of naked t-PA and t-PA@iRNP, measured using t-PA's ability to hydrolyze a tri-peptide chromogenic substrates of H-D-isoleucyl-L-prolyl-L-arginine-p-nitroanilide dihydrochloride to p-nitroaniline. Liberated p-nitroaniline was measured spectrophotometrically at $405 \mathrm{~nm}$ by using a UV-Vis spectrometer [113]. (c) Tumor growth profile in a C-26 colon murine cancer model, intravenously administered (5 times) with saline (control), t-PA (0.04 mM), and iRNP (TEMPO; $5.3 \mathrm{mM}$ ). (d) Representative images of fibrin immunofluorescence (white arrow) in the tumor tissues, scale bar $10 \mu \mathrm{m}$. (e) Superoxide level in tumor tissue homogenate measured by ROS sensitive dye, dihydroethidium. (f) Tissue factor in tumor lysates measured by ELISA [112]. ${ }^{*} p<0.05$ was considered significant. This figure is reproduced with permission from References [112,113]. Copyright 2020, Elsevier Ltd.; Copyright 2019, Elsevier Ltd.

We also confirmed that the higher effect of t-PA@iRNP was due to higher fibrin degradation in the tumor area by t-PA (Figure 7d), decreased ROS (Figure 7e), and downregulated NF-kB by iRNP (data not shown). Both t-PA@iRNP and iRNP-treated group significantly reduced the expression of ROS-regulated tissue factor, which activates coagulation and platelets essential for tumor growth and metastasis increase (Figure 7f) $[114,115]$. Based on these results, it is clear that RNP possesses bidentate roles, viz., effective carriers for t-PA to target solid tumors and suitable anti-cancer drugs, which effectively scavenge overproduced ROS around the tumor environment. 


\subsubsection{RNPs Enhances the Therapeutic Efficiency of Pioglitazone on Prostate Cancer}

Pioglitazone belongs to thiazolidinediones family that shows efficacy in type 2 diabetes mellitus and cancer, accompanied by several adverse effects such as hepatotoxicity, cardiac abnormalities, and weight gain due to fluid retention [116]. In addition to severe toxicity exerted by pioglitazone, poor solubility and low bioavailability due to extensive liver metabolism are also its drawbacks [117]. Several reports have confirmed that liver metabolism of pioglitazone forms reactive oxidative intermediates that potentially damages hepatocytes [118]. Considering this, we prepared RNP encapsulated with pioglitazone $\left(\right.$ Pio@RNP ${ }^{\mathrm{N}}$ ) to prevent premature metabolism of pioglitazone in the liver by modulating its pharmacokinetics property and decrease its ROS-mediated adverse effect by TEMPO radical of RNP (Figure 8a) [116]. Pharmacokinetic studies revealed that oral administration of Pio@RNPN , enhanced systemic presence of pioglitazone (AUC: 113.2) to twice as compared to free pioglitazone (oral) (AUC: 51.2), whereas intravenous administration Pio@RNPN showed the highest plasma concentration of pioglitazone (AUC: 723.9) (Figure 8b). In this study, free pioglitazone was administered orally in a CMC formulation due to its low solubility, whereas no such issue was observed in the encapsulation of pioglitazone in RNP. Biodistribution studies confirmed that Pio@RNPN (intravenous; i.v.) accumulated highest in tumor tissues (10\% ID/g tissue) followed by oral administration of Pio@RNPN ${ }^{\mathrm{N}}(3.8 \%$ $\mathrm{ID} / \mathrm{g}$ tissue) and oral pioglitazone (1.2\% ID/g tissue) (Figure $8 \mathrm{c}$ ).

(a)

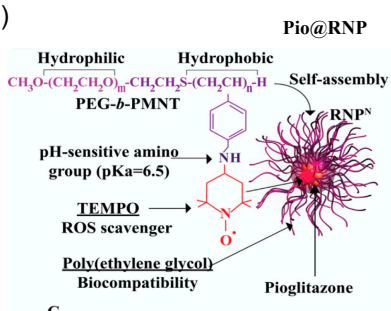

(d)

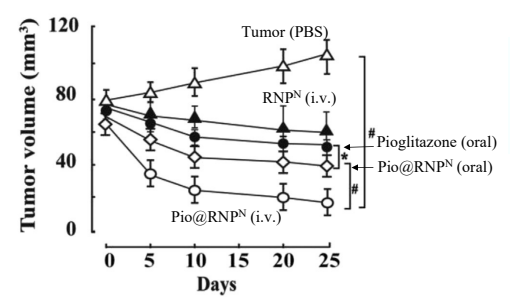

(e) (b)
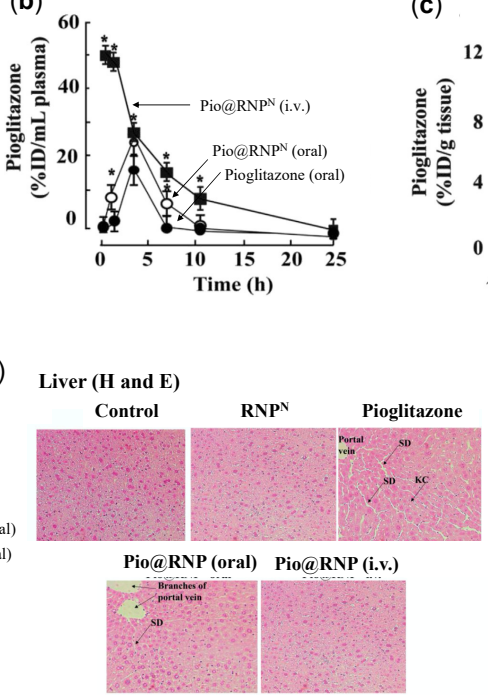

(c)

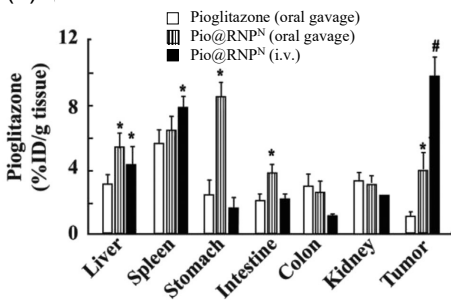

(f)

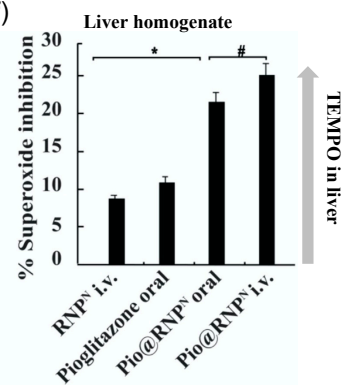

Figure 8. RNP increases the chemotherapeutic efficiency of pioglitazone (Pio) and suppresses its adverse effects. (a) Chemical structure of RNPN's polymer (PEG-b-PMNT) and illustration of pioglitazone encapsulated in RNPN . (b) Systemic bioavailability pioglitazone (oral), Pio@RNP ${ }^{\mathrm{N}}$ (oral), and Pio@ $\mathrm{RNP}^{\mathrm{N}}$ (i.v.) in mice administered with $15 \mathrm{mg} / \mathrm{kg}$ of pioglitazone. (c) Biodistribution of pioglitazone in various organs of mice after the treatment period of 25 days. (d) Tumor growth profile of prostate cancer (PC-3) in a mouse model, administered with PBS (control), free pioglitazone and Pio@ $\mathrm{RNP}^{\mathrm{N}}$ (Pio: $15 \mathrm{mg} / \mathrm{kg}$ and $\mathrm{RNP}^{\mathrm{N}}$ : $300 \mathrm{mg} / \mathrm{kg}$ ). (e) $\mathrm{RNP}^{\mathrm{N}}$ suppresses the adverse effect exerted by pioglitazone as assessed by liver histology stained by $\mathrm{H}$ and E (SD: sinusoidal dilatation, KC: Kupffer cells). (f) Superoxide inhibitory activity in liver homogenates administered with samples (from tumor xenograft studies) as evaluated by xanthine-xanthine oxidase assay [116]. ${ }^{*} p<0.05$ was considered significant. This figure is reproduced with permission from Reference [116]. Copyright 2016, Elsevier Ltd.

With such favorable pharmacokinetic properties of Pio@RNPN over free pioglitazone, its anti-cancer therapeutic efficacy was tested in a mouse xenograft model of prostate cancer (PC-3) (Figure 8d). At the experimental endpoint, orally administered pioglitazone reduced tumor volume by only 25\%, Pio@RNP ${ }^{\mathrm{N}}$ (oral) by 36\%, while Pio@RNPN (i.v.) showed the highest anti-tumor effect with $60 \%$ growth inhibition. In addition, intravenous 
administration of Pio@RNP ${ }^{\mathrm{N}}$ largely protected the liver toxicity exerted by ROS induced by the pioglitazone treatment (Figure 8e). An ex vivo xanthine/xanthine oxidase (superoxide scavenging) assay was conducted to measure the ROS scavenging effect of the TEMPO in the liver homogenates of the treated mice. In this assay, the xanthine/xanthine oxidase system generates superoxide ion radicals detected by nitro blue tetrazolium. When liver homogenates from treated mice are spiked with xanthine/xanthine oxidase, the generated superoxide ions are scavenged by antioxidants in liver homogenates, in our case, nitroxide radical (TEMPO). Higher the TEMPO in the liver homogenates, the higher the superoxide inhibition/scavenging ability. Figure 8f shows that Pio@RNPN (i.v.) exerts highest superoxide ion inhibition potential than orally administered Pio@RNP ${ }^{\mathrm{N}}$, and pioglitazone itself, suggesting the localization of $\mathrm{RNP}^{\mathrm{N}}$ in liver which might have contributed to the inhibition of pioglitazone-mediated adverse effect. This data corroborated with the result of lipid peroxidation status in the liver. We confirmed that Pio@RNPN (i.v.) treated group had a significantly lower lipid peroxidation level than pioglitazone (data not shown). These reports highlights the potential of $\mathrm{RNP}^{\mathrm{N}}$ as a DDS that increases the therapeutic efficacy of pioglitazone and decreases its adverse effects.

\subsubsection{RNPs Enhances the Therapeutic Efficiency of Doxorubicin on Colon Cancer and Epidermoid Cancers}

The effectiveness of cancer chemotherapy is greatly limited due to the drug-resistant characteristics of tumor cells, attributed largely to their drug efflux system [119]. It is reported that P-glycoprotein (P-gp) and multi-drug resistance-associated protein-1 (MRP1), which belong to the ATP-binding cassette $(\mathrm{ABC})$ transporter superfamily, are overexpressed in various cancers [120]. P-gp and MRP-1 both have been reported to confer resistance to various cancers against anti-cancer drugs [121]. With this fact in mind, several drug combination approaches have been applied that use ABC transporter inhibitors as adjuvants to overcome the drug resistance and potentiate the anti-cancer drug efficacy. For instance, administration of dofequidar, a P-gp inhibitor, with anti-cancer drugs such as cyclophosphamide, doxorubicin (Dox) and fluorouracil to patients with advanced or recurrent breast cancer, increased progression-free survival days from 241 (without P-gp inhibitor) to 366 [122]. However, several clinical trials have largely failed to manifest the therapeutic efficacy of such anti-cancer drugs/adjuvants. For instance, no improvement in the disease-free survival was observed in recurring or refractory multiple myeloma patients with and without P-gp inhibitor, valspodar, in conjunction with vincristine, Dox, and dexamethasone [123]. Although drug-efflux system inhibition for multi-drug resistance tumor therapy seems to be robust, these effects are not noteworthy. Binkhathlan et al. attributed the apparent failure of these adjuvants (drug efflux inhibitors) to demonstrate clinical efficacy to their non-specific action and distribution, causing toxicities due to their LMW [124]. Another possibility might be that the inhibitors themselves were not compelling enough. In this line, improved drug efflux inhibitors or the use of the delivery platform that specifically accumulates in the resistant tumors are highly desirable.

It was reported previously that oxidative stress is strongly related to this drug resistance. For example, ROS activates NF-kB, which increases drug efflux proteins such as P-gp and MRP-1, located in the cellular membrane [125]. It was also previously reported that P-gp and MRP-1 both are regulated independently by ROS in cancers [126,127]. Therefore, antioxidants are one of the candidates to suppress this drug resistance and increase the efficacy of anti-cancer drugs. Although pre-administration of LMW antioxidants such as edaravone and TEMPO have been evaluated to suppress the drug resistance of cancers, the results are not satisfactory $[60,128]$. Despite the fact that the antioxidant application for the chemoresistant cancer treatment may be in the right direction, however, they might not be effective due to the preferential clearance properties or low systemic retention as stated above. Therefore, in this line, we applied antioxidant RNPs to overcome the shortcoming of LMW drug efflux protein inhibitors/antioxidants by decreasing the ROS associated drug resistance. 
Dox, is known to generate ROS in vivo, which results in severe adverse effects in the normal tissues and increases the drug resistance of tumors [129]. Thus, we evaluated the ability of our RNPs to sensitize cancer cells and potentiate the efficacy of Dox by scavenging ROS in the colon and epidermoid cancer models. We have previously shown that intravenous administration of RNP accumulates significantly higher in C-26 colon tumors, while LMW TEMPOL excretes faster (Figure 4c,d) [82]. To confirm the sensitizing effect of RNPs, in a C-26 colon cancer model, we pre-administered RNPN (i.v.) for 4 days, followed by Dox administration $(10 \mathrm{mg} / \mathrm{kg})$ [82]. The $\mathrm{RNP}^{\mathrm{N}}+$ Dox-treated group showed the highest tumor growth suppression, followed by the free Dox administration group, as shown in the tumor growth profile graph (Figure 9a). It is interesting to see that pre-administration of TEMPOL did not decrease any tumor growth at all as compared to Dox alone, which indicates the poor systemic and tumor presence of TEMPOL compared to RNPN (Figure 4c,d and Figure 9a). As previously mentioned, Dox increases the ROS, which is one of the reasons for its off-target effects on the heart and several other organs. We confirmed that pre-administration of $\mathrm{RNP}^{\mathrm{N}}$ decreases the ROS in the heart tissues (Figure 9b), which prevented Dox-induced cardiotoxicity as assessed by creatine phosphokinase, a marker for myocardial damage (Figure 9c). Such protective effect was not seen in the TEMPOL treated group. These data implied that RNP not only potentiate the efficacy of Dox against colon cancer but also decreases its adverse effects.
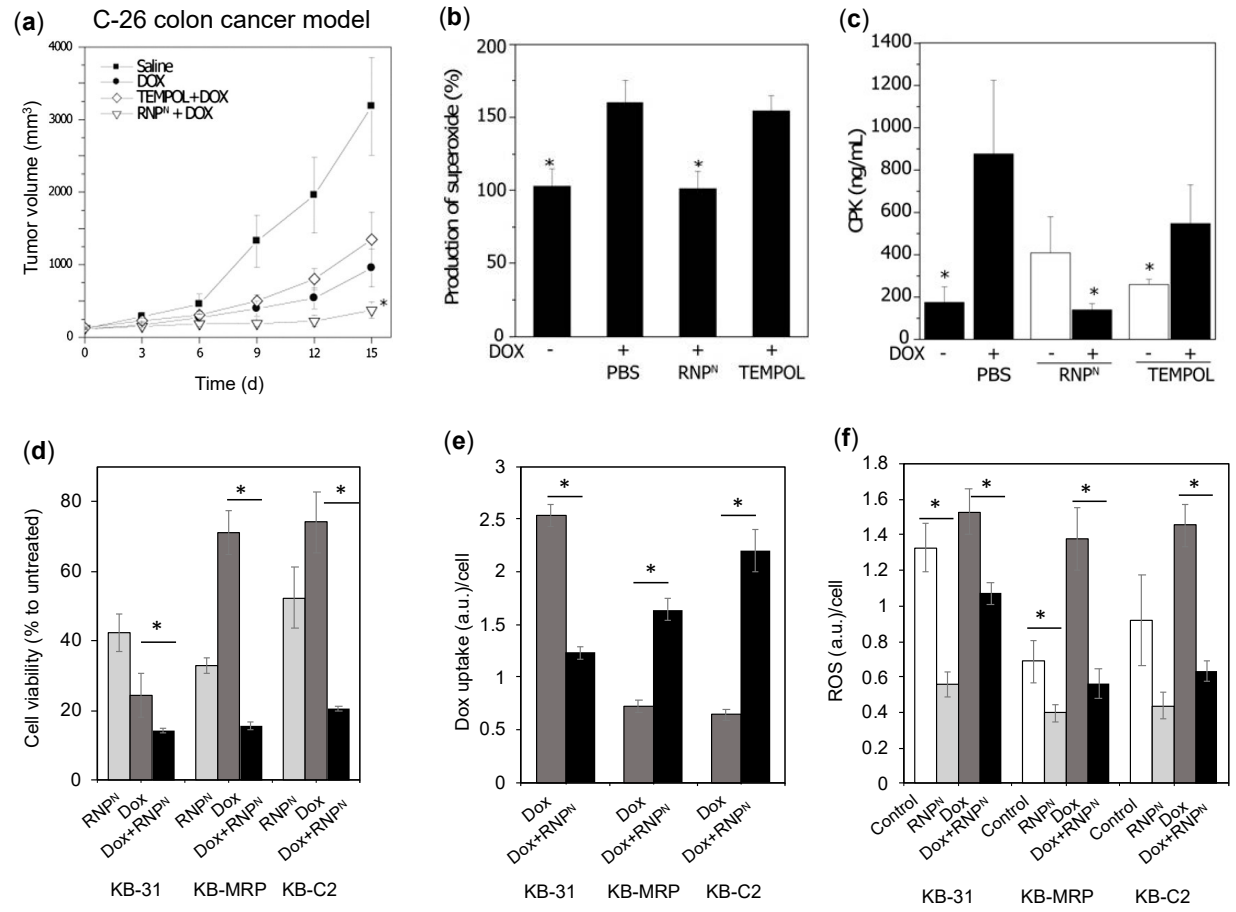

Figure 9. (top). RNP increases the therapeutic effect of doxorubicin (Dox) in a colon cancer model. (a) Tumor growth profile of subcutaneous colon tumor (C-26) pre-treated with $\mathrm{RNP}^{\mathrm{N}}$ (i.v., $100 \mathrm{mg} /$ day for 4 days, days -4 to -1 ), followed by a single injection of DOX (i.v., $10 \mathrm{mg} / \mathrm{kg}$ on day 0 ). The ability of RNPN to inhibit the cardiotoxicity of Dox mediated by increased ROS [82]; (b) inhibition of superoxide level by $\mathrm{RNP}^{\mathrm{N}}$ in the heart homogenates, (c) creatine phosphokinase (CPK) in plasma, a marker of heart damage. Mice were intravenously injected with $\mathrm{RNP}^{\mathrm{N}}(25 \mathrm{mg} / \mathrm{kg} /$ day $)$ and LMW-TEMPOL ( $4 \mathrm{mg} / \mathrm{kg} /$ day), followed by DOX (20 mg/kg, i.v.) $30 \mathrm{~min}$ later. 3 days post Dox administration, samples were analyzed. (bottom). RNPs increases the therapeutic effect of Dox by overcoming drug resistance in the epidermoid cancer cell lines. (d) Cytotoxicity of combination treatments: $\operatorname{RNP}^{\mathrm{N}}(2 \mathrm{mg} / \mathrm{mL})$ and Dox $(5 \mu \mathrm{g} / \mathrm{mL})$ for $48 \mathrm{~h}$ in epidermoid cancer cell lines-drug sensitive KB-31, drug-resistant KB-MRP overexpressing drug efflux transporter, MRP-1 and drug-resistant KB-C2 overexpressing drug efflux transporter, P-gp; (e) Dox uptake in epidermoid cancer cell lines after $2 \mathrm{~h}$ of treatment (RNP $(2 \mathrm{mg} / \mathrm{mL})$ and Dox $(5 \mu \mathrm{g} / \mathrm{mL}))$. (f) ROS level after $24 \mathrm{~h}$ of treatment with $\mathrm{RNP}^{\mathrm{N}}(2 \mathrm{mg} / \mathrm{mL})$ and Dox $(5 \mu \mathrm{g} / \mathrm{mL})$ in epidermoid cancer cell lines [130]. ${ }^{*} p<0.05$ was considered significant. This figure is reproduced with permission from Reference [82] and adapted from [130]. Copyright 2013, Elsevier B.V.; Copyright 2017, Elsevier Ltd. 
In our next study, we confirmed this effect by co-treatment of $\mathrm{RNP}^{\mathrm{N}}$ with Dox in 3 different types of epidermoid cancer cells: Drug-sensitive KB-31, drug-resistant KB-C2 (overexpressing P-gp) and KB-MRP (overexpressing MRP-1) (Figure 9d-f) [130]. As shown in Figure 9d, the viability of resistant cancer cell lines with the combination treatment of $\mathrm{RNP}^{\mathrm{N}}+$ Dox decreases significantly as compared to the Dox alone (48 $\mathrm{h}$ treatment). These significantly different efficiencies corroborated with Dox uptake tendencies; where in $\mathrm{RNP}^{\mathrm{N}}$ treatment $(2 \mathrm{~h})$, a significantly higher Dox uptake was observed in contrast to cells without RNPN (Figure 9e). Figure 9 f shows that ROS is elevated in the resistant cancer cells that may further confer resistance to the cancer cells, which was significantly reduced upon $\mathrm{RNP}^{\mathrm{N}}$ treatment. It should be noted that the drug-sensitive cell line, KB-31, was sensitive to RNP and Dox treatment, with high internalization of Dox, confirming negligible drug resistance level due to low drug efflux proteins. These data imply that the antioxidant activity of RNP is essential to modulate the drug efflux proteins by scavenging regulatory ROS, allowing the enhanced internalization and toxicity of Dox. Based on these data, it is concluded that RNP is a potential antioxidant to decrease the drug resistance of various cancers.

\section{Conclusions}

Cancers are characterized by persistent elevated intracellular ROS, critical for their survival, proliferation, angiogenesis, and metastasis. Therefore, the use of antioxidants is a suitable choice of therapeutic interventions to impede tumorigenesis. However, the failure of LMW antioxidants to inhibit tumors clinically accentuates the need for new therapeutic strategies to limit various cancers. In this line, our newly developed selfassembling antioxidants, $\mathrm{RNP}^{\mathrm{O}}$ and $\mathrm{RNP}^{\mathrm{N}}$, both have shown effective ROS-reduction mediated anti-cancer effect in vitro and in vivo as stand-alone or as an adjuvant to reduce aggressiveness and/or sensitize several cancers for chemotherapy. Higher bioavailability, specific tumor accumulation, and negligible toxicity of RNPs make them more suitable antioxidant therapeutic intervention than LMW counterparts for the cancer treatment. Recently, several other groups have started antioxidant therapy based on their own design. For instance, Moriyama et al., prepared antioxidant micelles from poly (ethylene glycol)b-poly (dopamine) block copolymers that inhibits angiogenesis in the chicken ex ovo chorioallantoic membrane assay [131]. Rocha et al., also developed epigallocatechin-3gallate incorporated polysaccharide nanoparticles which inhibited Du145 prostate cancer cells in vitro [132]. Including their work, the authors hope to establish a new field for antioxidant-based cancer therapeutics.

Author Contributions: Original draft preparation, review and editing, B.S. and Y.N. All authors have read and agreed to the published version of the manuscript.

Funding: This research received no external funding.

Institutional Review Board Statement: Not applicable.

Informed Consent Statement: Not applicable.

Data Availability Statement: Not applicable.

Acknowledgments: We would like to thank Nguyen Le Bui Thao for her assistance in the literature search.

Conflicts of Interest: The authors declare no conflict of interest.

\section{References}

1. Mukherji, S.M.; Singh, S.P. Reaction Mechanism in Organic Chemistry; Macmillan India Press: Chennai, India, 1986.

2. Gomberg, M. An incidence of trivalent carbon trimethylphenyl. J. Am. Chem. Soc. 1900, 22, 757-771. [CrossRef]

3. Gerschman, R.; Gilbert, D.L.; Nye, S.W.; Dwyer, P.; Fenn, W.O. Oxygen poisoning and x-irradiation: A mechanism in common. Science 1954, 119, 623-626. [CrossRef]

4. McCord, J.M.; Fridovich, I. Superoxide dismutase. an enzymic function for erythrocuprein (hemocuprein). J. Biol. Chem. 1969, 24, 6049-6055. [CrossRef] 
5. Halliwell, B. Free radicals and other reactive species in disease. In Nature Encyclopedia of Life Sciences; Nature Publishing Group: London, UK, 2001; pp. 1-7.

6. Phaniendra, A.; Jestadi, D.B.; Periyasamy, L. Free radicals: Properties, sources, targets, and their implication in various diseases. Indian J. Clin. Biochem. 2015, 30, 11-26. [CrossRef] [PubMed]

7. McCord, J.M.; Fridovich, I. Free radicals, antioxidants in disease and health. Int. J. Biomed. Sci. 2008, 4, 89-96.

8. Dreher, D.; Junod, A.F. Role of oxygen free radicals in cancer development. Eur. J. Cancer 1996, 32, 30-38. [CrossRef]

9. Fuchs-Tarlovsky, V. Role of antioxidants in cancer therapy. Nutrition 2013, 29, 15-21. [CrossRef]

10. Morry, J.; Ngamcherdtrakul, W.; Yantasee, W. Oxidative stress in cancer and fibrosis: Opportunity for therapeutic intervention with antioxidant compounds, enzymes, and nanoparticles. Redox. Biol. 2017, 11, 240-253. [CrossRef]

11. Perillo, B.; Di Donato, M.; Pezone, A.; Zazzo, E.D.; Giovannelli, P.; Galasso, G.; Castoria, G.; Migliaccio, A. ROS in cancer therapy: The bright side of the moon. Exp. Mol. Med. 2020, 202052, 192-203. [CrossRef]

12. Hsie, A.W.; Recio, L.; Katz, D.S.; Lee, C.Q.; Wagner, M.; Schenley, R.L. Evidence for reactive oxygen species inducing mutations in mammalian cells. Proc. Natl. Acad. Sci. USA 1986, 83, 9616-9620. [CrossRef]

13. Weiss, S.J. Tissue destruction by neutrophils. N. Engl. J. Med. 1989, 320, 365-376. [PubMed]

14. Terzić, J.; Grivennikov, S.; Karin, E.; Karin, M. Inflammation and colon cancer. Gastroenterology 2010, 138, 2101-2114. [CrossRef] [PubMed]

15. Ames, B.N.; Shigenaga, M.K.; Hagen, T.M. Oxidants, antioxidants, and the degenerative diseases of aging. Proc. Natl. Acad. Sci. USA 1993, 90, 7915-7922. [CrossRef] [PubMed]

16. Shigenaga, M.K.; Gimeno, C.J.; Ames, B.N. Urinary 8-hydroxy- 2-deoxyguanosine as a biological marker of in vivo oxidative DNA damage. Proc. Natl. Acad. Sci. USA 1989, 86, 9697-9701. [CrossRef]

17. Valko, M.; Rhodes, C.J.; Moncol, J.; Izakovic, M.; Mazur, M. Free radicals, metals and antioxidants in oxidative stress-induced cancer. Chem. Biol. Interact. 2006, 160, 1-40. [CrossRef]

18. Ames, B.N. Dietary carcinogens and anticarcinogens. Oxygen radicals and degenerative diseases. Science 1983, 221, 1256-1264. [CrossRef]

19. Lindahl, T. Instability and decay of the primary structure of DNA. Nature 1993, 362, 709-715. [CrossRef]

20. Marnett, L.J. Oxyradicals and DNA damage. Carcinogenesis 2000, 21, 361-370. [CrossRef]

21. Cooke, M.S.; Evans, M.D.; Dizdaroglu, M.; Lunec, J. Oxidative DNA damage: Mechanisms, mutation, and disease. FASEB J. 2003, 17, 1195-1214. [CrossRef]

22. Prior, I.A.; Lewis, P.D.; Mattos, C. A comprehensive survey of Ras mutations in cancer. Cancer Res. 2012, 72, 2457-2467. [CrossRef]

23. Xu, W.; Trepel, J.; Neckers, L. Ras, ROS and proteotoxic stress: A delicate balance. Cancer Cell 2011, 20, 281-282. [CrossRef]

24. Vousden, K.H.; Lane, D.P. p53 in health and disease. Nat. Rev. Mol. Cell Biol. 2007, 8, 275-283. [CrossRef] [PubMed]

25. Maillet, A.; Pervaiz, S. Redox regulation of p53, redox effectors regulated by p53: A subtle balance. Antioxid. Redox Signal. 2012, 16, 1285-1294. [CrossRef] [PubMed]

26. He, Z.; Simon, H.U. A novel link between p53 and ROS. Cell Cycle 2013, 12, 201-202. [CrossRef] [PubMed]

27. Perri, F.; Pisconti, S.; Della Vittoria Scarpati, G. P53 mutations and cancer: A tight linkage. Ann. Transl. Med. $2016,4,522$. [CrossRef] [PubMed]

28. Vogelstein, B.; Kinzler, K.W. p53 function and dysfunction. Cell 1992, 70, 523-526. [CrossRef]

29. Amiri, K.I.; Richmond, A. Role of nuclear factor-kappa B in melanoma. Cancer Metast. Rev. 2005, 24, 301-313. [CrossRef]

30. Nakajima, S.; Kitamura, M. Bidirectional regulation of NF- $\kappa B$ by reactive oxygen species: A role of unfolded protein response. Free Radic. Biol. Med. 2013, 65, 162-174. [CrossRef]

31. Knight, J.A. Free radicals, antioxidants, and the immune system. Ann. Clin. Lab. Sci. 2000, 30, 145-158.

32. Xia, L.; Tan, S.; Zhou, Y.; Lin, J.; Wang, H.; Oyang, L.; Tian, Y.; Liu, L.; Su, M.; Wang, H.; et al. Role of the NFkB-signaling pathway in cancer. OncoTargets Ther. 2018, 11, 2063-2073. [CrossRef]

33. Larsson, R.; Cerutti, P. Translocation and enhancement of phosphotransferase activity of protein kinase C following exposure in mouse epidermal cells to oxidants. Cancer Res. 1989, 49, 5627-5632. [PubMed]

34. Gopalakrishna, R.; Anderson, W. $\mathrm{Ca}^{2+}$-and phospholipid-independent activation of protein kinase $\mathrm{C}$ by selective oxidative modification of the regulatory domain. Proc. Natl. Acad. Sci. USA 1989, 86, 6758-6762. [CrossRef]

35. Lopez-Ilasaca, M.; Crespo, P.; Pellici, P.G.; Gutkind, J.S.; Wetzker, R. Linkage of G protein-coupled receptors to the MAPK signaling pathway through PI 3-kinase gamma. Science 1997, 275, 394-397. [CrossRef] [PubMed]

36. Gao, N.; Jiang, B.H.; Leonard, S.S.; Corum, L.; Zhang, Z.; Roberts, J.R.; Antonini, J.; Zheng, J.Z.; Flynn, D.C.; Castranova, V.; et al. p38 Signaling-mediated hypoxia-inducible factor 1 alpha and vascular endothelial growth factor induction by Cr (VI) in DU145 human prostate carcinoma cells. J. Biol. Chem. 2002, 277, 45041-45048. [CrossRef] [PubMed]

37. Hsu, T.C.; Young, M.R.; Cmarik, J.; Colburn, N.H. Activator protein 1 (AP-1)- and nuclear factor kappa B (NF-kappa B)- dependent transcriptional events in carcinogenesis. Free Rad. Biol. Med. 2000, 28, 1338-1348. [CrossRef]

38. Huang, C.; Li, J.; Costa, M.; Zhang, Z.; Leonard, S.S.; Castranova, V.; Vallyathan, V.; Ju, G.; Shi, X. Hydrogen peroxide mediates activation of nuclear factor of activated T cells (NFAT) by nickel sulfide. Cancer Res. 2001, 61, 8051-8057. [PubMed]

39. Mancini, M.; Toker, A. NFAT proteins: Emerging roles in cancer progression. Nat. Rev. Cancer. 2009, 9, 810-820. [CrossRef]

40. Um, H.D. Bcl-2 family proteins as regulators of cancer cell invasion and metastasis: A review focusing on mitochondrial respiration and reactive oxygen species. Oncotarget 2016, 7, 5193-5203. [CrossRef] 
41. Sharma, M.; Rajappa, M.; Kumar, G.; Sharma, A. Oxidant-antioxidant status in Indian patients with carcinoma of posterior one-third of tongue. Cancer Biomark. 2009, 5, 253-260. [CrossRef]

42. Lee, Y.J.; Lee, D.M.; Lee, C.H.; Heo, S.H.; Won, S.Y.; Im, J.H.; Cho, M.K.; Nam, H.S.; Lee, S.H. Suppression of human prostate cancer PC-3 cell growth by N-acetylcysteine involves over-expression of Cyr61. Toxicol. In Vitro 2011, 25, 199-205. [CrossRef]

43. Lee, M.F.; Chan, C.Y.; Hung, H.C.; Chou, I.T.; Yee, A.S.; Huang, C.Y. N-acetylcysteine (NAC) inhibits cell growth by mediating the EGFR/Akt/HMG box-containing protein 1 (HBP1) signaling pathway in invasive oral cancer. Oral Oncol. 2013, 49, 129-135. [CrossRef] [PubMed]

44. Lv, H.; Wang, C.; Fang, T.; Li, T.; Lv, G.; Han, Q.; Yang, W.; Wang, H. Vitamin C preferentially kills cancer stem cells in hepatocellular carcinoma via SVCT-2. NPJ Precis. Oncol. 2018, 2, 1. [CrossRef] [PubMed]

45. Zeng, L.H.; Wang, Q.M.; Feng, L.Y.; Ke, Y.D.; Xu, Q.Z.; Wei, A.Y.; Zhang, C.; Ying, R.B. High-dose vitamin C suppresses the invasion and metastasis of breast cancer cells via inhibiting epithelial-mesenchymal transition. OncoTargets Ther. 2019, 12, 7405-7413. [CrossRef] [PubMed]

46. Turley, J.M.; Fu, T.; Ruscetti, F.W.; Mikovits, J.A.; Bertolette, D.C., 3rd; Birchenall-Roberts, M.C. Vitamin E succinate induces Fas-mediated apoptosis in estrogen receptor-negative human breast cancer cells. Cancer Res. 1997, 57, 881-890. [PubMed]

47. Weiping, Y.; Qiao, Y.L.; Feras, M.; Hantash, B.G. Sanders and Kimberly Kline. Activation of extracellular signal-regulated kinase and c-Jun- $\mathrm{NH}_{2}$-terminal kinase but not p38 mitogen-activated protein kinases is required for RRR- $\alpha$-Tocopheryl succinate-induced apoptosis of human breast cancer cells. Cancer Res. 2001, 61, 6569-6576.

48. Choi, J.A.; Kim, J.Y.; Lee, J.Y.; Kang, C.M.; Kwon, H.J.; Yoo, Y.D.; Kim, T.W.; Lee, Y.S.; Lee, S.J. Induction of cell cycle arrest and apoptosis in human breast cancer cells by quercetin. Int. J. Oncol. 2001, 19, 837-844. [CrossRef]

49. Pratheeshkumar, P.; Budhraja, A.; Son, Y.O.; Wang, X.; Zhang, Z.; Ding, S.; Wang, L.; Hitron, A.; Lee, J.C.; Xu, M.; et al. Quercetin inhibits angiogenesis mediated human prostate tumor growth by targeting VEGFR- 2 regulated AKT/mTOR/P70S6K signaling pathways. PLoS ONE 2012, 7, e47516. [CrossRef]

50. Richter, M.; Ebermann, R.; Marian, B. Quercetin-induced apoptosis in colorectal tumor cells: Possible role of EGF receptor signaling. Nutr. Cancer 1999, 34, 88-99. [CrossRef]

51. Wilcox, C.S. Effects of tempol and redox-cycling nitroxides in models of oxidative stress. Pharmacol. Ther. 2010, 126, 119-145. [CrossRef]

52. Münzel, T.; Afanas'ev, I.B.; Kleschyov, A.L.; Harrison, D.G. Detection of superoxide in vascular tissue. Arter. Thromb. Vasc. Biol. 2002, 22, 1761-1768. [CrossRef]

53. Soule, B.P.; Hyodo, F.; Matsumoto, K.; Simone, N.L.; Cook, J.A.; Krishna, M.C.; Mitchell, J.B. The chemistry and biology of nitroxide compounds. Free Radic. Biol. Med. 2007, 42, 1632-1650. [CrossRef] [PubMed]

54. Suy, S.; Mitchell, J.B.; Ehleiter, D.; Haimovitz-Friedman, A.; Kasid, U. Nitroxides tempol and tempo induce divergent signal transduction pathways in MDA-MB 231 breast cancer cells. J. Biol. Chem. 1998, 273, 17871-17878. [CrossRef] [PubMed]

55. Gariboldi, M.B.; Lucchi, S.; Caserini, C.; Supino, R.; Oliva, C.; Monti, E. Antiproliferative effect of the piperidine nitroxide TEMPOL on neoplastic and nonneoplastic mammalian cell lines. Free Radic. Biol. Med. 1998, 24, 913-923. [CrossRef]

56. Gariboldi, M.B.; Rimoldi, V.; Supino, R.; Favini, E.; Monti, E. The nitroxide tempol induces oxidative stress, p21(WAF1/CIP1), and cell death in HL60 cells. Free Radic. Biol. Med. 2000, 29, 633-641. [CrossRef]

57. Gariboldi, M.B.; Ravizza, R.; Petterino, C.; Castagnaro, M.; Finocchiaro, G.; Monti, E. Study of in vitro and in vivo effects of the piperidine nitroxide Tempol-a potential new therapeutic agent for gliomas. Eur. J. Cancer 2003, 39, 829-837. [CrossRef]

58. Schubert, R.; Erker, L.; Barlow, C.; Yakushiji, H.; Larson, D.; Russo, A.; Mitchell, J.B.; Wynshaw-Boris, A. Cancer chemoprevention by the antioxidant tempol in Atm-deficient mice. Hum. Mol. Genetics 2004, 13, 1793-1802. [CrossRef] [PubMed]

59. Mitchell, J.B.; Xavier, S.; DeLuca, A.M.; Sowers, A.L.; Cook, J.A.; Krishna, M.C.; Hahn, S.M.; Russo, A.A. A low molecular weight antioxidant decreases weight and lowers tumor incidence. Free Rad. Biol. Med. 2003, 34, 93-102. [CrossRef]

60. Suy, S.; Mitchell, J.B.; Samuni, A.; Mueller, S.; Kasid, U. Nitroxide tempo, a small molecule, induces apoptosis in prostate carcinoma cells and suppresses tumor growth in athymic mice. Cancer 2005, 103, 1302-1313. [CrossRef]

61. Klein, E.A.; Thompson, I.M.; Tangen, C.M., Jr.; Crowley, J.J.; Lucia, M.S.; Goodman, P.J.; Minasian, L.M.; Ford, L.G.; Parnes, H.L.; Gaziano, J.M.; et al. Vitamin E and the risk of prostate cancer: The selenium and vitamin E cancer prevention trial (SELECT). JAMA 2011, 306, 1549-1556. [CrossRef]

62. Lippman, S.M.; Klein, E.A.; Goodman, P.J.; Lucia, M.S.; Thompson, I.M.; Ford, L.G.; Parnes, H.L.; Minasian, L.M.; Gaziano, J.M.; Hartline, J.A.; et al. Effect of selenium and vitamin E on risk of prostate cancer and other cancers: The Selenium and Vitamin E Cancer Prevention Trial (SELECT). JAMA 2009, 301, 39-51. [CrossRef]

63. Neuhouser, M.L.; Barnett, M.J.; Kristal, A.R.; Ambrosone, C.B.; King, I.B.; Thornquist, M.; Goodman, G.G. Dietary supplement use and prostate cancer risk in the carotene and retinol efficacy trial. Cancer Epidemiol. Biomark. 2009, 18, 2202-2206. [CrossRef] [PubMed]

64. Blot, W.J.; Li, J.Y.; Taylor, P.R.; Guo, W.; Dawsey, S.; Wang, G.Q.; Yang, C.S.; Zheng, S.F.; Gail, M.; Li, G.Y.; et al. Nutrition intervention trials in Linxian, China: Supplementation with specific vitamin/mineral combinations, cancer incidence, and disease-specific mortality in the general population. J. Natl. Cancer Inst. 1993, 85, 1483-1492. [CrossRef] [PubMed]

65. Goodman, G.E.; Thornquist, M.D.; Balmes, J.; Cullen, M.R.; Meyskens, F.L., Jr.; Omenn, G.S.; Valanis, B.; Williams, J.H., Jr. The beta-carotene and retinol efficacy rrial: Incidence of lung cancer and cardiovascular disease mortality during 6-year follow-up after stopping beta-carotene and retinol supplements. J. Natl. Cancer Inst. 2004, 96, 1743-1750. [CrossRef] [PubMed] 
66. Radak, Z.; Zhao, Z.; Koltai, E.; Ohno, H.; Atalay, M. Oxygen consumption and usage during physical exercise: The balance between oxidative stress and ROS-dependent adaptive signaling. Antioxid. Redox Signal. 2013, 18, 1208-1246. [CrossRef] [PubMed]

67. Bjelakovic, G.; Nikolova, D.; Gluud, L.L.; Simonetti, R.G.; Gluud, S. Mortality in randomized trials of antioxidant supplements for primary and secondary prevention. JAMA 2007, 297, 842-857. [CrossRef] [PubMed]

68. Gal, L.K.; Ibrahim, M.; Wiel, C.; Sayin, V.; Akula, M.; Karlsson, C. Antioxidants can increase melanoma metastasis in mice. Sci. Transl. Med. 2015, 7, 308re8. [CrossRef] [PubMed]

69. Porporato, P.E.; Payen, V.L.; Perez-Escuredo, J.; Saedeleer, C.J.; Danhier, P.A.; Copetti, T.; Suveera, D.; Tardy, M.; Vazeille, T.; Bouzin, C.; et al. Mitochondrial switch promotes tumor metastasis. Cell Rep. 2014, 8, 754-766. [CrossRef]

70. Matsumura, Y.; Maeda, H. A new concept for macromolecular therapeutics in cancer chemotherapy: Mechanism of tumoritropic accumulation of proteins and the antitumor agent smancs. Cancer Res. 1986, 46, 6387-6392.

71. Rezaei-Sadabady, R.; Eidi, A.; Zarghami, N.; Barzegar, A. Intracellular ROS protection efficiency and free radical-scavenging activity of quercetin and quercetin-encapsulated liposomes. Artif. Cells Nanomed. Biotechnol. 2016, 44, 128-134. [CrossRef]

72. Hijaz, M.; Das, S.; Mert, I.; Gupta, A.; Al-Wahab, Z.; Tebbe, C.; Sajad, D.; Chinna, J.; Giri, S.; Munkarah, A.; et al. Folic acid tagged nanoceria as a novel therapeutic agent in ovarian cancer. BMC Cancer 2016, 16, 220. [CrossRef]

73. Morry, J.; Ngamcherdtrakul, W.; Gu, S.; Reda, M.; Castro, D.J.; Sangvanich, T.; Gray, J.W.; Yantasee, W. Targeted treatment of metastatic breast cancer by PLK1 siRNA delivered by an antioxidant nanoparticle platform. Mol. Cancer Ther. 2017, 16, 763-772. [CrossRef] [PubMed]

74. Li, L.; Liu, T.; Fu, C.; Tan, L.; Meng, X.; Liu, H. Biodistribution, excretion, and toxicity of mesoporous silica nanoparticles after oral administration depend on their shape. Nanomedicine 2015, 11, 1915-1924. [CrossRef] [PubMed]

75. Yoshitomi, T.; Nagasaki, Y. Reactive oxygen species-scavenging nanomedicines for the treatment of oxidative stress injuries. Adv. Healthc. Mater. 2014, 3, 1149-1161. [CrossRef] [PubMed]

76. Yoshitomi, T.; Nagasaki, Y. Nitroxyl radical-containing nanoparticles for novel nanomedicine against oxidative stress injury. Nanomedicine 2011, 6, 509-518. [CrossRef]

77. Yoshitomi, T.; Hirayama, A.; Nagasaki, Y. The ROS scavenging and renal protective effects of pH-responsive nitroxide radicalcontaining nanoparticles. Biomaterials 2011, 32, 8021-8028. [CrossRef]

78. Yoshitomi, T.; Suzuki, R.; Mamiya, T.; Matsui, H.; Hirayama, A.; Nagasaki, Y. pH-Sensitive radical-containing-nanoparticle (RNP) for the L-Band-EPR imaging of low pH circumstances. Bioconjugate Chem. 2009, 20, 1792-1798. [CrossRef]

79. Francis, M.; Cristea, M.; Winnik, F. Polymeric micelles for oral drug delivery: Why and how. Pure Appl. Chem. 2004, 76, 1321-1335. [CrossRef]

80. Suk, J.S.; Xu, Q.; Kim, N.; Hanes, J.; Ensign, L.M. PEGylation as a strategy for improving nanoparticle-based drug and gene delivery. Adv. Drug Deliv. Rev. 2016, 99, 28-51. [CrossRef]

81. Sha, S.; Vong, L.B.; Chonpathompikunlert, P.; Yoshitomi, T.; Matsui, H.; Nagasaki, Y. Suppression of NSAID-induced small intestinal inflammation by orally administered redox nanoparticles. Biomaterials 2013, 34, 8393-8400. [CrossRef]

82. Yoshitomi, T.; Ozaki, Y.; Thangavel, S.; Nagasaki, Y. Redox nanoparticle therapeutics to cancer-Increase in therapeutic effect of doxorubicin, suppressing its adverse effect. J. Control. Release 2013, 172, 137-143. [CrossRef]

83. Choi, H.S.; Liu, W.; Misra, P.; Tanaka, E.; Zimmer, J.P.; Ipe, B.I.; Bawendi, M.G.; Frangioni, J. Renal clearance of nanoparticles. Nat. Biotechnol. 2017, 25, 1165-1170. [CrossRef] [PubMed]

84. Li, S.D.; Huang, L. Pharmacokinetics and biodistribution of nanoparticles. Mol. Pharm. 2008, 5, 496-504. [CrossRef] [PubMed]

85. Shimizu, M.; Yoshitomi, T.; Nagasaki, Y. The behavior of ROS scavenging nanoparticles in blood. J. Clin. Biochem. 2014, 54, 166-173. [CrossRef]

86. Nagasaki, Y. Design and application of redox polymers for nanomedicine. Polym. J. 2018, 50, 821-836. [CrossRef]

87. Monti, E.; Supino, R.; Colleoni, M.; Costa, B.; Ravizza, R.; Gariboldi, M.B. Nitroxide TEMPOL impairs mitochondrial function and induces apoptosis in HL60 cells. J. Cell. Biochem. 2001, 82, 271-276. [CrossRef] [PubMed]

88. Vong, L.B.; Kobayashi, M.; Nagasaki, Y. Evaluation of the toxicity and antioxidant activity of redox nanoparticles in Zebrafish (Danio rerio) embryos. Mol. Pharm. 2016, 13, 3091-3097. [CrossRef] [PubMed]

89. Hahn, S.M.; Tochner, Z.; Krishna, C.M.; Glass, J.; Wilson, L.; Samuni, A.; Sprague, M.; Venzon, D.; Glatstein, E.; Mitchell, J.B.; et al. Tempol, a stable free radical, is a novel murine radiation protector. Cancer Res. 1992, 52, 1750-1753.

90. Magalhães, P.A.; de Brito, T.S.; Freire, R.S.; da Silva, M.T.; dos Santos, A.A.; Vale, M.L.; de Menezes, D.B.; Martins, A.M.; Libório, A.B. Metabolic acidosis aggravates experimental acute kidney injury. Life Sci. 2016, 146, 58-65. [CrossRef]

91. Azamjah, N.; Soltan-Zadeh, Y.; Zayeri, F. Global trend of breast cancer mortality rate: A 25-Year Study. Asian Pac. J. Cancer Prev. 2019, 20, 2015-2020. [CrossRef]

92. Yeh, C.C.; Hou, M.F.; Tsai, S.M.; Lin, S.K.; Hsiao, J.K.; Huang, J.C.; Wang, L.H.; Wu, S.H.; Hou, L.A.; Ma, H.; et al. Superoxide anion radical, lipid peroxides and antioxidant status in the blood of patients with breast cancer. Clin. Chim. Acta 2005, 361, 101-111. [CrossRef]

93. Renschler, F. The emerging role of reactive oxygen species in cancer therapy. Eur. J. Cancer 2004, 40, 1934-1940. [CrossRef] [PubMed]

94. Kumaraguruparan, R.; Subapriya, R.; Kablimoorthy, J.; Nagini, S. Antioxidant profile in the circulation of patients with fibroadenoma and adenocarcinoma of the breast. Clin. Biochem. 2002, 35, 275-279. [CrossRef] 
95. Rigiracciolo, D.C.; Scarpelli, A.; Lappano, R.; Pisano, A.; Santolla, M.F.; De Marco, P.; Cirillo, F.; Cappello, A.R.; Dolce, V.; Belfiore, A.; et al. Copper activates HIF-1alpha/GPER/VEGF signalling in cancer cells. Oncotarget 2015, 6, 34158-34177. [CrossRef] [PubMed]

96. Menon, S.G.; Coleman, M.C.; Walsh, S.A.; Spitz, D.R.; Goswami, P.C. Differential susceptibility of nonmalignant human breast epithelial cells and breast cancer cells to thiol antioxidant-induced G(1)-delay. Antioxid. Redox Signal. 2005, 7, 711-718. [CrossRef] [PubMed]

97. Kundu, N.; Zhang, S.; Fulton, A.M. Sublethal oxidative stress inhibits tumor cell adhesion and enhances experimental metastasis of murine mammary carcinoma. Clin. Exp. Metastasis 1995, 13, 16-22. [CrossRef]

98. Shashni, B.; Nagasaki, Y. Nitroxide radical-containing nanoparticles attenuate tumorigenic potential of triple negative breast cancer. Biomaterials 2018, 178, 48-62. [CrossRef]

99. Shashni, B.; Horiguchi, Y.; Kurosu, K.; Furusho, H.; Nagasaki, Y. Application of surface enhanced Raman spectroscopy as a diagnostic system for hypersialylated metastatic cancers. Biomaterials 2017, 134, 143-153. [CrossRef]

100. Duffy, M.J.; Maguire, T.M.; Hill, A.; McDermott, E.; Higgins, N.O. Metal-loproteinases: Role in breast carcinogenesis, invasion and metastasis. Breast Cancer Res. 2000, 2, 252-257. [CrossRef]

101. Bull, C.; Stoel, M.A.; Brok, M.H.D.; Adema, G.J. Sialic acids sweeten a tumor's life. Cancer Res. 2014, 74, 3199-3204. [CrossRef]

102. Coussens, L.M.; Werb, Z. Inflammation and cancer. Nature 2002, 420, 860-867. [CrossRef]

103. Gommeaux, J.; Cano, C.; Garcia, S.; Gironella, M.; Pietri, S.; Culcasi, M.; Gommeaux, J.; Pébusque, M.J.; Malissen, B.; Dusetti, N.; et al. Colitis and colitis-associated cancer are exacerbated in mice deficient for tumor protein 53-induced nuclear protein 1. Mol. Cell. Biol. 2007, 27, 2215-2228. [CrossRef] [PubMed]

104. Tenesa, A.; Dunlop, M.G. New insights into the aetiology of colorectal cancer from genome-wide association studies. Nat. Rev. Genet. 2009, 10, 353-358. [CrossRef] [PubMed]

105. Vong, L.B.; Yoshitomi, T.; Matsui, H.; Nagasaki, Y. Development of an oral nanotherapeutics using redox nanoparticles for treatment of colitis-associated colon cancer. Biomaterials 2015, 55, 54-63. [CrossRef] [PubMed]

106. Vong, L.B.; Tomita, T.; Yoshitomi, T.; Matsui, H.; Nagasaki, Y. An orally administered redox nanoparticle that accumulates in the colonic mucosa and reduces colitis in mice. Gastroenterology 2012, 143, 1027-1036. [CrossRef] [PubMed]

107. Minchinton, A.I.; Tannock, I.F. Drug penetration in solid tumours. Nat. Rev. 2006, 6, 583-592. [CrossRef]

108. Netti, P.A.; Berk, D.A.; Swartz, M.A.; Grodzinsky, A.J.; Jain, R.K. Role of extracellular matrix assembly in interstitial transport in solid tumors. Cancer Res. 2000, 60, 2497-2503.

109. Mars, W.M.; Zarnegar, R.; Michalopoulos, G.K. Activation of hepatocyte growth factor by the plasminogen activators uPA and tPA. Am. J. Pathol. 1993, 143, 949-958.

110. Zhang, B.; Jiang, T.; She, X.; Shen, S.; Wang, S.; Deng, J.; Shi, W.; Mei, H.; Hu, Y.; Pang, Z.; et al. Fibrin degradation by rtPA enhances the delivery of nanotherapeutics to A549 tumors in nude mice. Biomaterials 2016, 96, 63-71. [CrossRef]

111. Nilsson, T.; Wallen, P.; Mellbring, G. In vivo metabolism of human tissue-type plasminogen activator. Scand. J. Haematol. 1984, 33, 49-53. [CrossRef]

112. Mei, T.; Shashni, B.; Maeda, H.; Nagasaki, Y. Fibrinolytic tissue plasminogen activator installed redox-active nanoparticles (t-PA@iRNP) for cancer therapy. Biomaterials 2020, 259, 120290. [CrossRef]

113. Mei, T.; Kim, A.; Vong, L.B.; Marushima, A.; Puentes, S.; Matsumaru, Y.; Matsumura, A.; Nagasaki, Y. Encapsulation of tissue plasminogen activator in $\mathrm{pH}$-sensitive self-assembled antioxidant nanoparticles for ischemic stroke treatment-Synergistic effect of thrombolysis and antioxidant. Biomaterials 2019, 215, 119209. [CrossRef] [PubMed]

114. Fernandez, P.M.; Patierno, S.R.; Rickles, F.R. Tissue factor and fibrin in tumor angiogenesis. Semin. Thromb. Hemost. 2004, 30, 31-44. [PubMed]

115. Cadroy, Y.; Dupouy, D.; Boneu, B.; Plaisancié, H. Polymorphonuclear leukocytes modulate tissue factor production by mononuclear cells: Role of reactive oxygen species. J. Immunol. 2000, 164, 3822-3828. [CrossRef] [PubMed]

116. Thangavel, S.; Yoshitomi, T.; Sakharkar, M.K.; Nagasaki, Y. Redox nanoparticle increases the chemotherapeutic efficiency of pioglitazone and suppresses its toxic side effects. Biomaterials 2016, 99, 109-123. [CrossRef] [PubMed]

117. Floyd, J.S.; Barbehenn, E.; Lurie, P.; Wolfe, S.M. Case series of liver failure associated with rosiglitazone and pioglitazone. Pharmaco epidemiol. Drug Saf. 2009, 18, 1238-1243.

118. Rabbani, S.I.; Devi, K.; Khanam, S. Role of pioglitazone with metformin or glimepiride on oxidative stress-induced nuclear damage and reproductive toxicity in diabetic rats. Malays. J. Med. Sci. 2010, 17, 3-11.

119. Fojo, T.; Menefee, M. Mechanisms of multidrug resistance: The potential role of microtubule-stabilizing agents. Ann. Oncol. 2007, 18, v3-v8. [CrossRef]

120. Holohan, C.; Schaeybroeck, S.V.; Longley, D.B.; Johnston, P.G. Cancer drug resistance: An evolving paradigm. Nat. Rev. 2013, 13, 714-726. [CrossRef]

121. Housman, G.; Byler, S.; Heerboth, S.; Lapinska, K.; Longacre, M.; Snyder, N.; Sarkar, S. Drug resistance in cancer: An overview. Cancers 2014, 6, 1769-1792. [CrossRef]

122. Saeki, T.; Nomizu, T.; Toi, M.; Ito, Y.; Noguchi, S.; Kobayashi, T.; Asaga, T.; Minami, H.; Yamamoto, N.; Aogi, K.; et al. Dofequidar fumarate (MS-209) in combination with cyclophosphamide, doxorubicin, and fluorouracil for patients with advanced or recurrent breast cancer. J. Clin. Oncol. 2007, 25, 411-417. [CrossRef] 
123. Friedenberg, W.R.; Rue, M.; Blood, E.A.; Dalton, W.S.; Shustik, C.; Larson, R.A.; Sonneveld, P.; Greipp, P.R. Phase III study of PSC-833 (valspodar) in combination with vincristine, doxorubicin, and dexamethasone (valspodar/VAD) versus VAD alone in patients with recurring or refractory multiple myeloma (E1A95): A trial of the Eastern Cooperative Oncology Group. Cancer 2006, 106, 830-838. [CrossRef] [PubMed]

124. Binkhathlan, Z.; Lavasanifar, A. P-glycoprotein inhibition as a therapeutic approach for overcoming multidrug resistance in cancer: Current status and future perspectives. Curr. Cancer Drug Targets 2013, 13, 326-346. [CrossRef] [PubMed]

125. Bentires-Alj, M.; Barbu, V.; Fillet, M.; Chariot, A.; Relic, B.; Jacobs, N.; Gielen, J.; Merville, M.P.; Bours, B. NF- $\kappa$ B transcription factor induces drug resistance through MDR1 expression in cancer cells. Oncogene 2003, 22, 90-97. [CrossRef] [PubMed]

126. Szakacs, G.; Paterson, J.K.; Ludwig, J.A.; Booth-Genthe, C.; Gottesman, M.M. Targeting multidrug resistance in cancer. Nat. Rev. Drug Discov. 2006, 5, 219-234. [CrossRef] [PubMed]

127. Rivera, E. Implications of anthracycline-resistant and taxane-resistant meta- static breast cancer and new therapeutic options. Breast J. 2010, 16, 252-263. [CrossRef]

128. Kokura, S.; Yoshida, N.; Sakamoto, N.; Ishikawa, T.; Takagi, T.; Higashihara, H.; Nakabe, N.; Handa, O.; Naito, Y.; Yoshikawa, $\mathrm{T}$. The radical scavenger edaravone enhances the anti-tumor effects of CPT-11 in murine colon cancer by increasing apoptosis viainhibition of NF-kappaB. Cancer Lett. 2005, 229, 223-233. [CrossRef] [PubMed]

129. DeAtley, S.M.; Aksenov, M.Y.; Aksenova, M.V.; Jordan, B.; Carney, J.M.; Butterfield, D.A. Adriamycin-induced changes of creatine kinase activity in vivo and in cardiomyocyte culture. Toxicology 1999, 134, 51-62. [CrossRef]

130. Shashni, B.; Alshwimi, A.; Minami, M.; Furukawa, T.; Nagasaki, T. Nitroxide radical-containing nanoparticles as potential candidates for overcoming drug resistance in epidermoid cancers. Polymer 2017, 116, 429-438. [CrossRef]

131. Moriyama, M.; Metzger, S.; van der Vlies, A.J.; Uyama, H.; Ehrbar, M.; Hasegawa, U. Inhibition of angiogenesis by antioxidant micelles. Adv. Healthc. Mater. 2015, 4, 569-575. [CrossRef]

132. Rocha, S.; Generalov, R.; Pereira Mdo, C.; Peres, I.; Juzenas, P.; Coelho, M.A. Epigallocatechin gallate-loaded polysaccharide nanoparticles for prostate cancer chemoprevention. Nanomedicine 2011, 6, 79-87. [CrossRef] 